\title{
LEVEL II SCOUR ANALYSIS FOR BRIDGE 54 (LUDLTH03560054) on TOWN HIGHWAY 356, crossing JEWELL BROOK LUDLOW, VERMONT Open-File Report 98-92
}

U.S. Department of the Interior U.S. Geological Survey

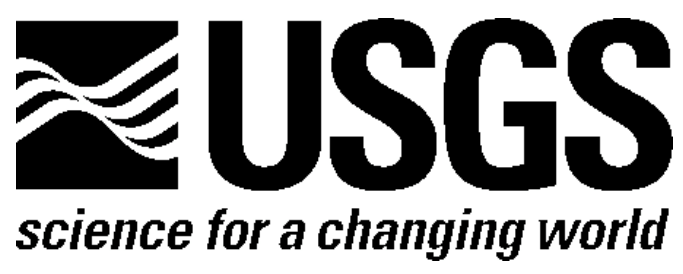




\section{LEVEL II SCOUR ANALYSIS FOR BRIDGE 54 (LUDLTH03560054) on TOWN HIGHWAY 356, crossing JEWELL BROOK, LUDLOW, VERMONT}

By SUSAN A. WILLOUGHBY and MICHAEL A. IVANOFF

U.S. Geological Survey

Open-File Report 98-92

Prepared in cooperation with

VERMONT AGENCY OF TRANSPORTATION and

FEDERAL HIGHWAY ADMINISTRATION 


\title{
U.S. DEPARTMENT OF THE INTERIOR BRUCE BABBITT, Secretary
}

\author{
U.S. GEOLOGICAL SURVEY
}

Thomas J. Casadevall, Acting Director

For additional information write to:

District Chief

U.S. Geological Survey 361 Commerce Way

Pembroke, NH 03275-3718
Copies of this report may be purchased from:

U.S. Geological Survey

Branch of Information Services

Open-File Reports Unit

Box 25286

Denver, CO 80225-0286 


\section{CONTENTS}

Conversion Factors, Abbreviations, and Vertical Datum ........................................................................... iv

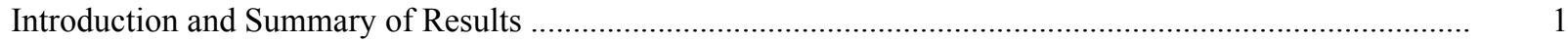

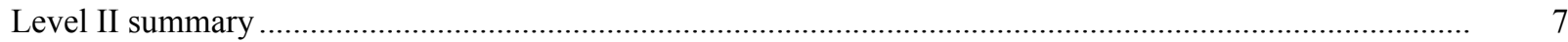

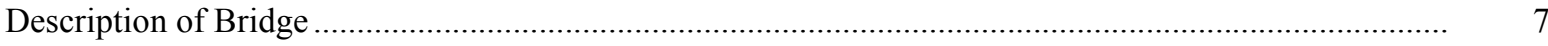

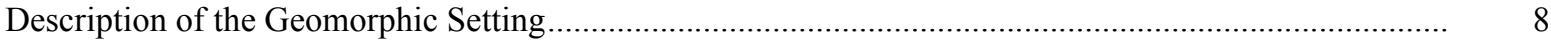

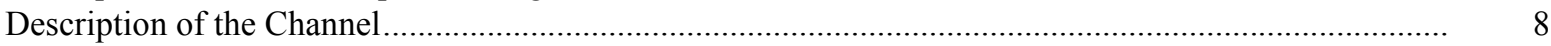

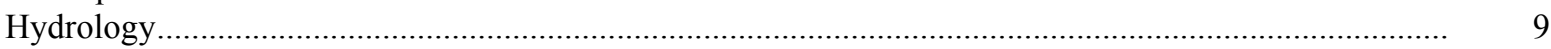

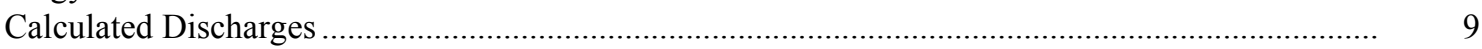

Description of the Water-Surface Profile Model (WSPRO) Analysis ........................................................

Cross-Sections Used in WSPRO Analysis ............................................................................

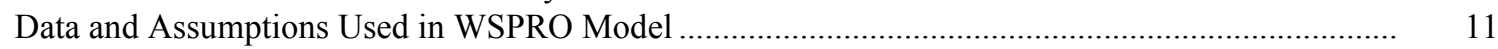

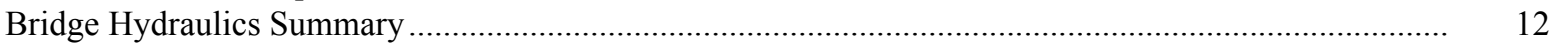

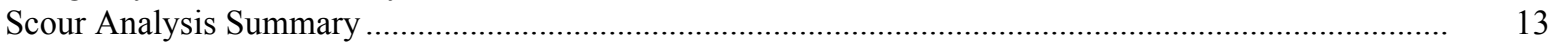

Special Conditions or Assumptions Made in Scour Analysis ............................................................ 13

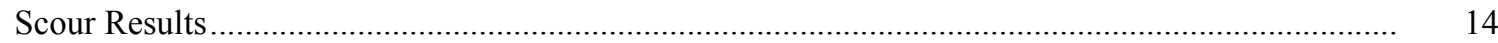

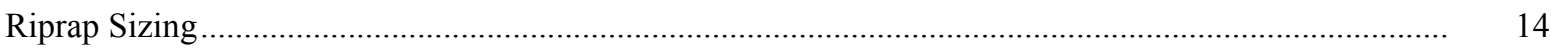

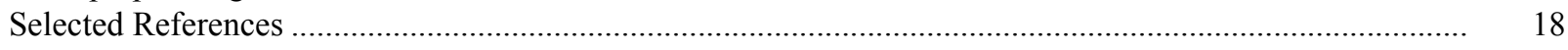

Appendices:

A. WSPRO input file

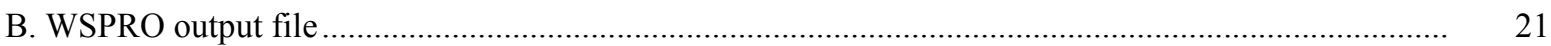

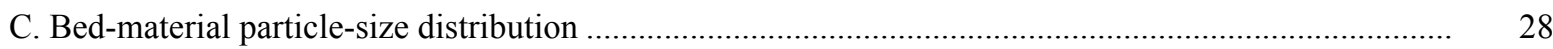

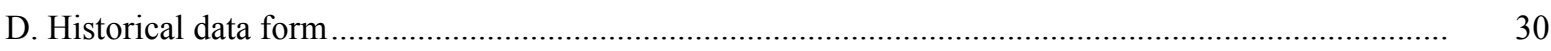

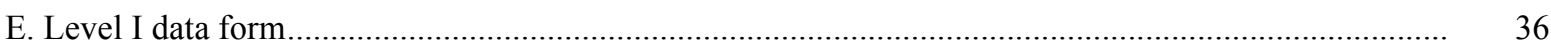

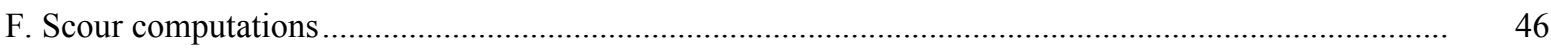

\section{FIGURES}

1. Map showing location of study area on USGS 1:24,000 scale map ...........................................................

2. Map showing location of study area on Vermont Agency of Transportation town

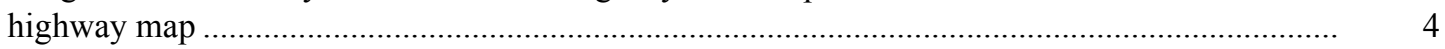

3. Structure LUDLTH03560054 viewed from upstream (October 12, 1995) ……...................................... 5

4. Downstream channel viewed from structure LUDLTH03560054 (October 12, 1995).............................. 5

5. Upstream channel viewed from structure LUDLTH03560054 (October 12, 1995)..................................... 6

6. Structure LUDLTH03560054 viewed from downstream (October 12, 1995)........................................... 6

7. Water-surface profiles for the 100 - and 500-year discharges at structure

LUDLTH03560054 on Town Highway 356, crossing Jewell Brook,

Ludlow, Vermont.

8. Scour elevations for the 100 - and 500 -year discharges at structure

LUDLTH03560054 on Town Highway 54, crossing Jewell Brook,

Ludlow, Vermont.

\section{TABLES}

1. Remaining footing/pile depth at abutments for the 100-year discharge at structure

LUDLTH03560054 on Town Highway 356, crossing Jewell Brook,

Ludlow, Vermont

2. Remaining footing/pile depth at abutments for the 500-year discharge at structure

LUDLTH03560054 on Town Highway 356, crossing Jewell Brook, Ludlow Vermont 


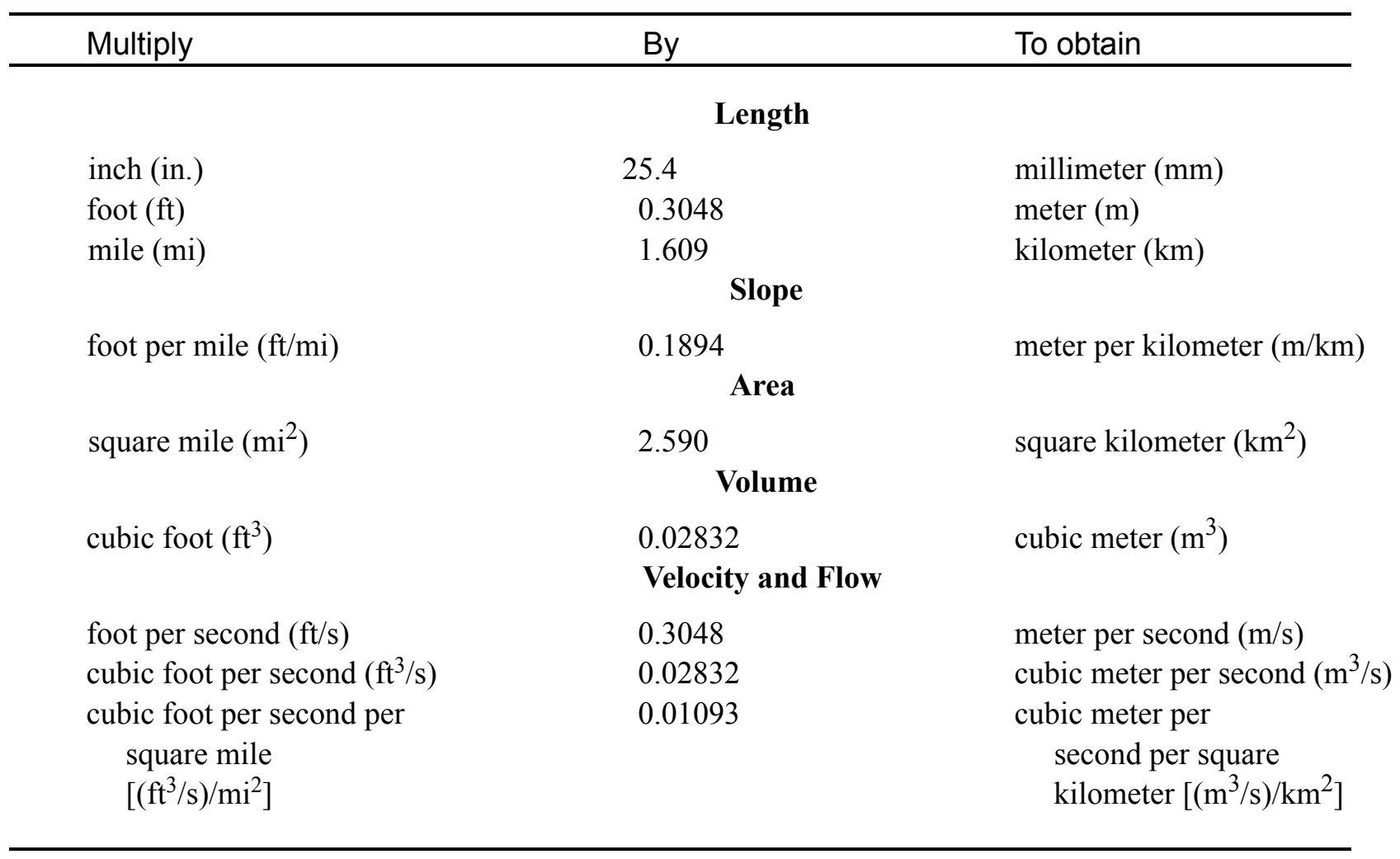

\section{OTHER ABBREVIATIONS}

$\begin{array}{lrlr}\text { BF } & \text { bank full } & & \\ \text { cfs } & \begin{array}{r}\text { cubic feet per second } \\ \text { LWW }\end{array} & \text { left wingwall } \\ \mathrm{D}_{50} & \text { median diameter of bed material } & \text { MC } & \text { main channel } \\ \mathrm{DS} & \text { downstream } & \text { RAB } & \text { right abutment } \\ \text { elev. } & \text { elevation } & \text { RABUT } & \text { face of right abutment } \\ \mathrm{f} / \mathrm{p} & \text { flood plain } & \text { RB } & \text { right bank } \\ \mathrm{ft} & \text { square feet } & \text { ROB } & \text { right overbank } \\ \mathrm{ft} / \mathrm{ft} & \text { feet per foot } & \text { RWW } & \text { right wingwall } \\ \mathrm{FEMA} & \text { Federal Emergency Management Agency } & \text { TH } & \text { town highway } \\ \text { FHWA } & \text { Federal Highway Administration } & \text { UB } & \text { under bridge } \\ \text { JCT } & \text { junction } & \text { US } & \text { upstream } \\ \text { LAB } & \text { left abutment } & \text { USGS } & \text { United States Geological Survey } \\ \text { LABUT } & \text { face of left abutment } & \text { VTAOT } & \text { Vermont Agency of Transportation } \\ \text { LB } & \text { left bank } & \text { WSPRO } & \text { water-surface profile model } \\ \text { LOB } & \text { left overbank } & \text { yr } & \text { year }\end{array}$

In this report, the words "right" and "left" refer to directions that would be reported by an observer facing downstream. Sea level: In this report, "sea level" refers to the National Geodetic Vertical Datum of 1929-- a geodetic datum derived from a general adjustment of the first-order level nets of the United States and Canada, formerly called Sea Level Datum of 1929.

In the appendices, the above abbreviations may be combined. For example, USLB would represent upstream left bank. 


\title{
LEVEL II SCOUR ANALYSIS FOR BRIDGE 54 (LUDLTH03560054) ON TOWN HIGHWAY 356, CROSSING JEWELL BROOK, LUDLOW, VERMONT
}

\author{
By Susan A. Willoughby and Michael A. Ivanoff
}

\section{INTRODUCTION AND SUMMARY OF RESULTS}

This report provides the results of a detailed Level II analysis of scour potential at structure LUDLTH03560054 on Town Highway 356 crossing Jewell Brook, Ludlow, Vermont (figures 1-8). A Level II study is a basic engineering analysis of the site, including a quantitative analysis of stream stability and scour (Federal Highway Administration, 1993). Results of a Level I scour investigation also are included in appendix E of this report. A Level I investigation provides a qualitative geomorphic characterization of the study site. Information on the bridge, gleaned from Vermont Agency of Transportation (VTAOT) files, was compiled prior to conducting Level I and Level II analyses and is found in appendix D.

The site is in the Green Mountain section of the New England physiographic province in south central Vermont. The $10.3-\mathrm{mi}^{2}$ drainage area is in a predominantly rural and forested basin. In the vicinity of the study site, the surface cover upstream of the bridge is forest and trees with a road along the left bank; there is a road and a house on the right bank.

Downstream of the bridge, there are trees along the immediate banks, houses on the left side, and a road and houses along the right side.

In the study area, the Jewell Brook has an incised, straight channel with a slope of approximately $0.017 \mathrm{ft} / \mathrm{ft}$, an average channel top width of $56 \mathrm{ft}$ and an average bank height of $6 \mathrm{ft}$. The channel bed material ranges from gravel to boulders with a median grain size $\left(\mathrm{D}_{50}\right)$ of $88.0 \mathrm{~mm}(0.289 \mathrm{ft})$. The geomorphic assessment at the time of the Level I and Level II site visit on October 12, 1995, indicated that the reach was stable.

The Town Highway 356 crossing of Jewell Brook is a 41 - $\mathrm{ft}-$ long, two-lane concrete bridge consisting of five 37-foot rolled steel stringers (Vermont Agency of Transportation, written communication, March 20, 1995). The opening length of the structure parallel to the bridge face is $33 \mathrm{ft}$. The bridge is supported by vertical, concrete abutments with wingwalls; both abutments and wingwalls are faced with laid up stone. The channel is normal to the opening with a computed opening-skew-to-roadway of 0 degrees. 
A scour hole $0.5 \mathrm{ft}$ deeper than the mean thalweg depth was observed along the left abutment and downstream left wingwall during the Level I assessment. The only scour protection measure at the site was type-2 stone fill (less than 36 inches diameter) along the entire base length of the downstream right wingwall, and along both banks up and downstream. Additional details describing conditions at the site are included in the Level II Summary and appendices D and E.

Scour depths and recommended rock rip-rap sizes were computed using the general guidelines described in Hydraulic Engineering Circular 18 (Richardson and Davis, 1995) for the 100- and 500-year discharges. In addition, the incipient roadway-overtopping discharge was determined and analyzed as another potential worst-case scour scenario. Total scour at a highway crossing is comprised of three components: 1) long-term streambed degradation; 2) contraction scour (due to accelerated flow caused by a reduction in flow area at a bridge) and; 3 ) local scour (caused by accelerated flow around piers and abutments). Total scour is the sum of the three components. Equations are available to compute depths for contraction and local scour and a summary of the results of these computations follows.

Contraction scour for all modelled flows ranged from 0 to $1.0 \mathrm{ft}$. The worst-case contraction scour occurred at the 500-year discharge. Abutment scour ranged from 6.2 to $13.8 \mathrm{ft}$. The worst-case abutment scour occurred at the 500-year discharge. Additional information on scour depths and depths to armoring are included in the section titled "Scour Results". Scoured-streambed elevations, based on the calculated scour depths, are presented in tables 1 and 2. A cross-section of the scour computed at the bridge is presented in figure 8. Scour depths were calculated assuming an infinite depth of erosive material and a homogeneous particle-size distribution.

It is generally accepted that the Froehlich equation (abutment scour) gives "excessively conservative estimates of scour depths" (Richardson and Davis, 1995, p. 46). Usually, computed scour depths are evaluated in combination with other information including (but not limited to) historical performance during flood events, the geomorphic stability assessment, existing scour protection measures, and the results of the hydraulic analyses. Therefore, scour depths adopted by VTAOT may differ from the computed values documented herein. 


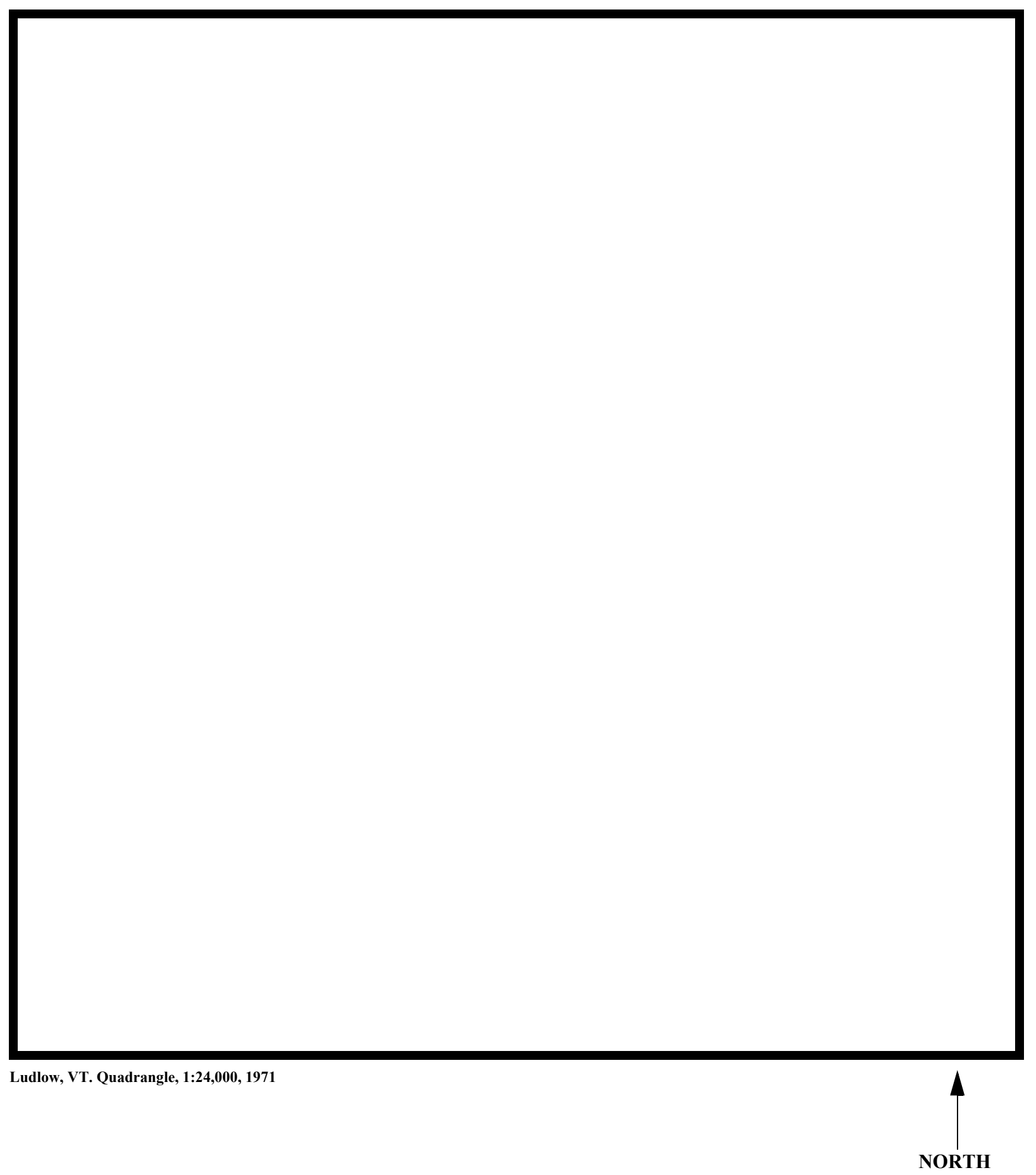

Figure 1. Location of study area on USGS 1:24,000 scale map. 
Figure 2. Location of study area on Vermont Agency of Transportation town highway map. 

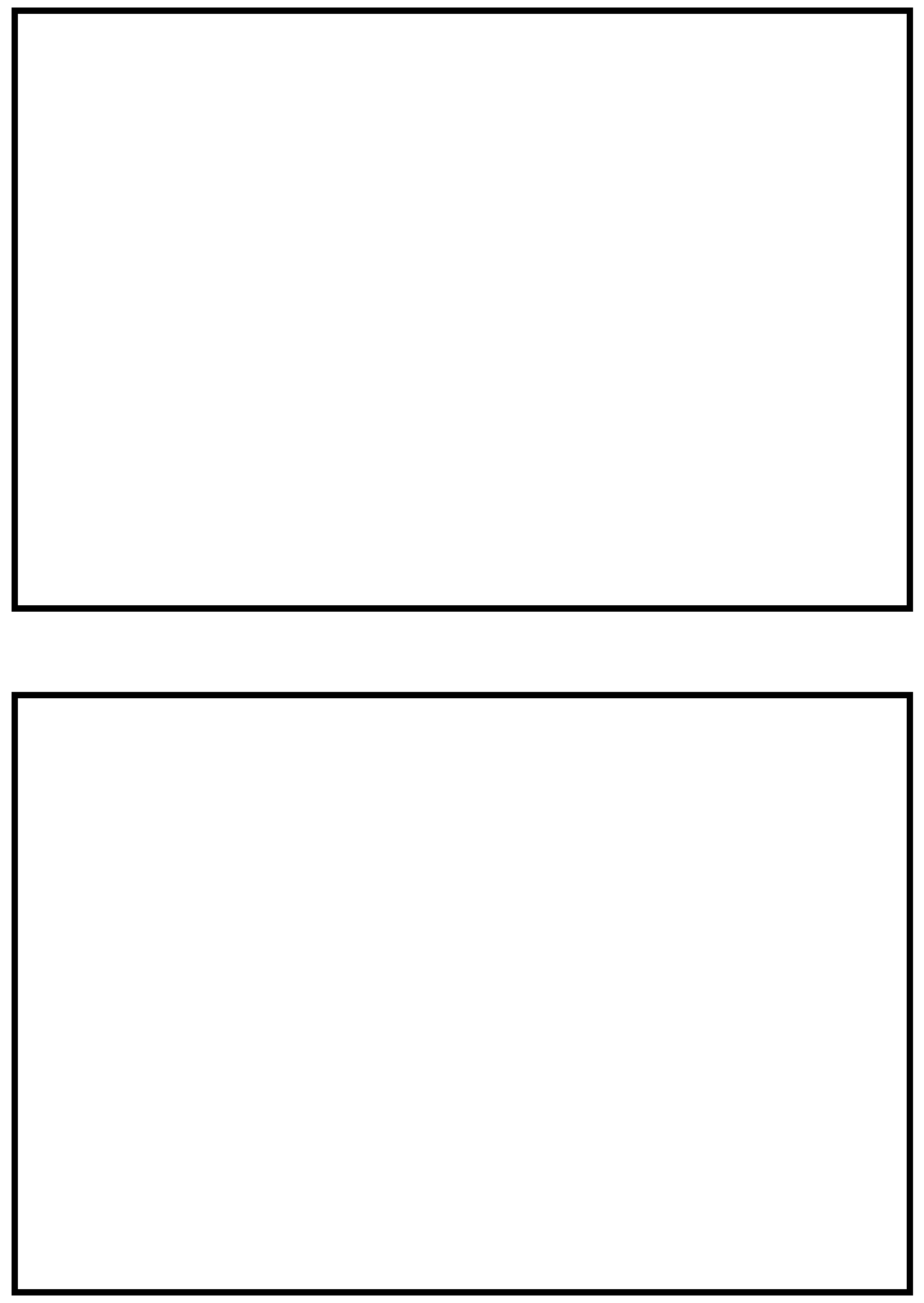

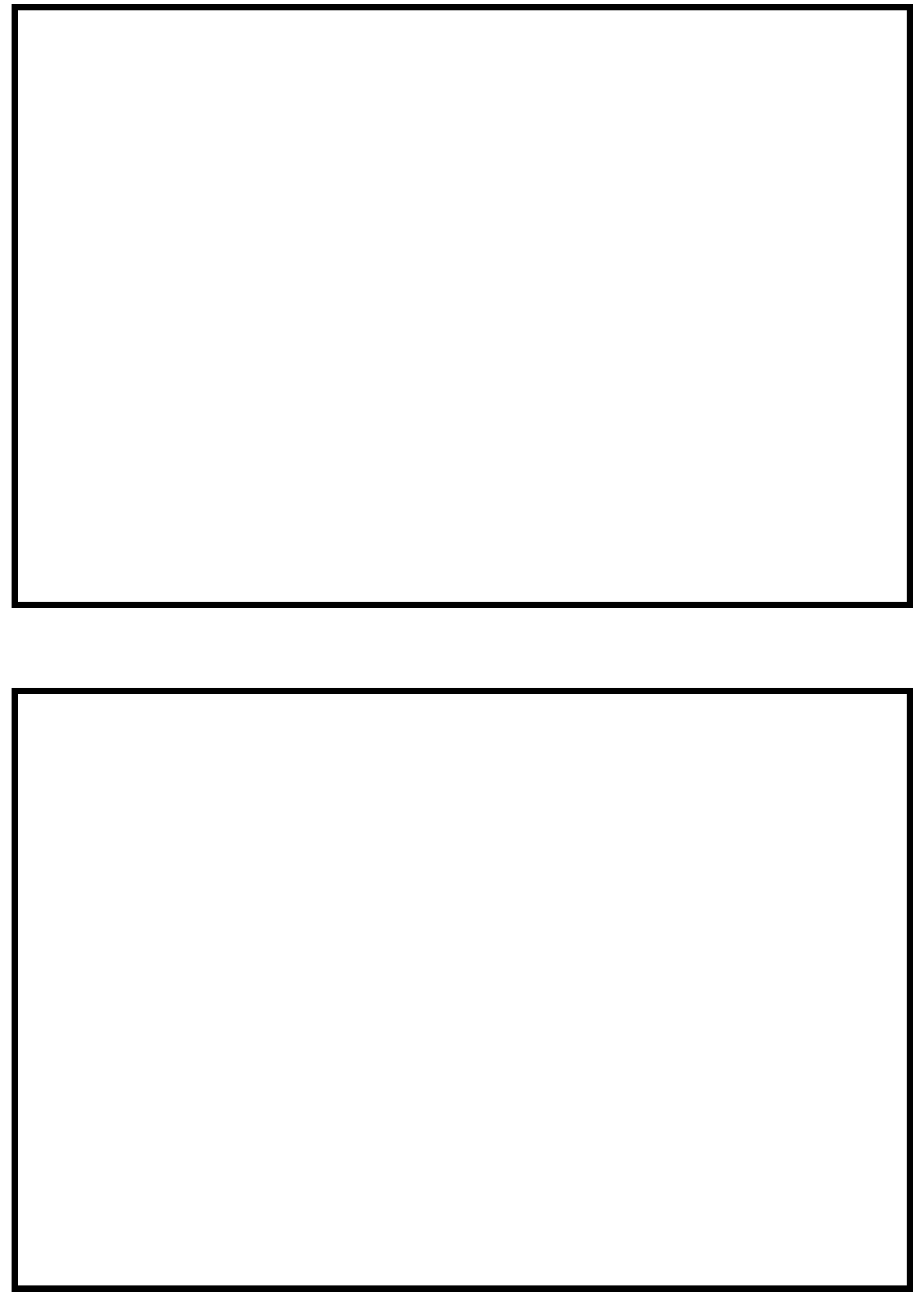


\section{LEVEL II SUMMARY}

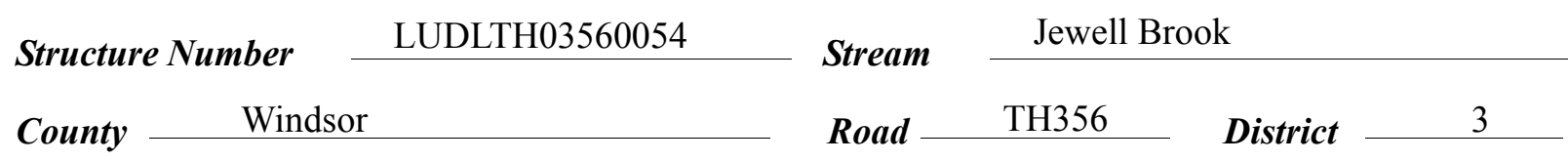

\section{Description of Bridge}

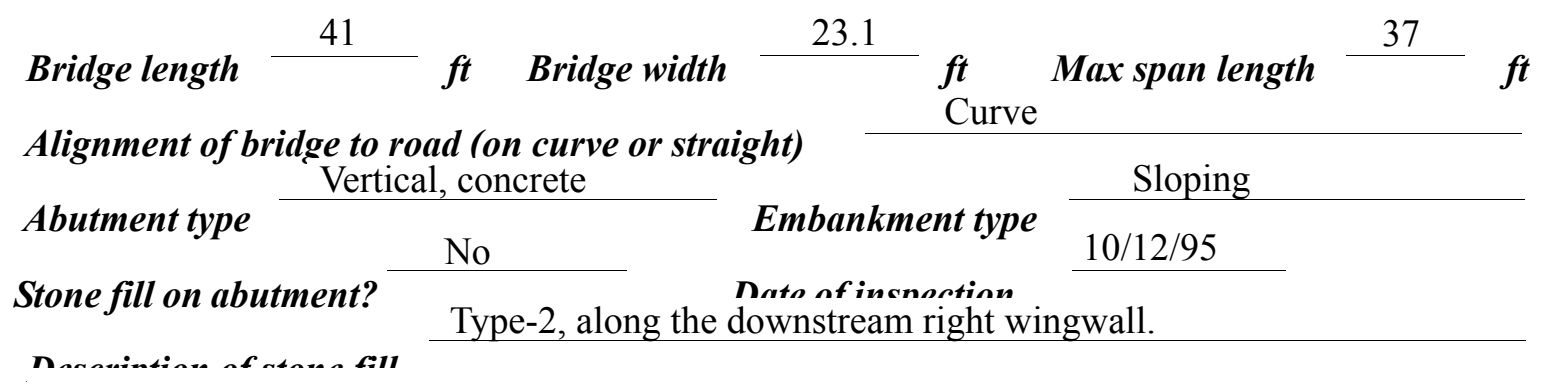

Abutments and wingwalls are concrete. The left

abutment is undermined for about 1.5 feet along the channel with a 0.3 foot penetration.

Is bridge skewed to flood flow according to No survey?

Debris accumulation on bridge at time of Level I or Level II site visit:

\begin{tabular}{|c|c|c|c|}
\hline & $\begin{array}{c}\text { Date of incnortion } \\
10 / 12 / 95 \\
\end{array}$ & $\begin{array}{l}\text { Percent of alommol } \\
\text { blocked inortzontatly }\end{array}$ & $\begin{array}{l}\text { Percent of a } \\
\text { blocked verticatty }\end{array}$ \\
\hline Level I & $10 / 12 / 95$ & 0 & 0 \\
\hline $\begin{array}{l}\text { Level II } \\
\text { flow. }\end{array}$ & \multicolumn{3}{|c|}{ Low. The stream channel widens near the bridge, allowing debris } \\
\hline
\end{tabular}

None, 10/12/95.

Doscriho any, foaturos noar ar at tho hridos that mav, affoct flou, (includo ahsorvation dato) 


\section{Description of the Geomorphic Setting}

General topography The channel is located within a moderate relief valley with a narrow flood plain on both sides.

Geomorphic conditions at bridge site: downstream (DS), upstream (US)

Date of inspection $\quad 10 / 12 / 95$

DS left: $\quad$ Steep channel bank to a mildly sloping overbank

DS right: $\quad$ Steep channel bank to a moderately sloping overbank and floodplain

US left: $\quad$ Steep channel bank to mildly sloping overbank

US right: $\quad$ Steep channel bank to mildly sloping overbank and floodplain

\section{Description of the Channel}

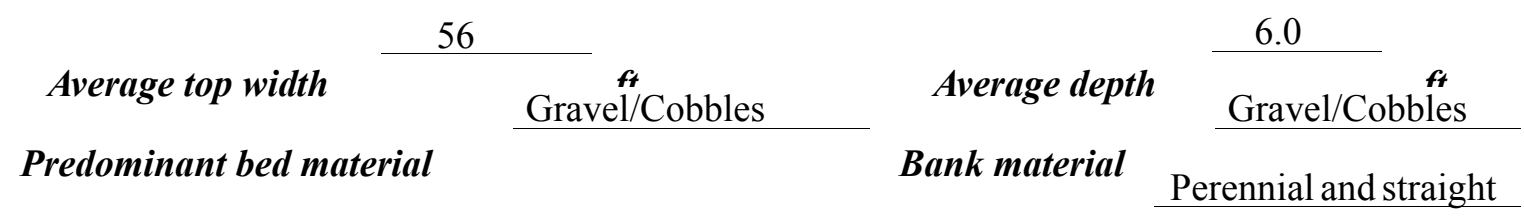

with random width variations and non-alluvial channel boundaries.

Vegetative co $^{1}$ Brush and grass with small trees along the immediate bank.

DS left: $\quad$ Brush and very small trees along immediate bank, then lawns and houses.

DS right: $\quad$ Trees and brush on the immediate bank with forest beyond.

US left: $\quad$ Small trees and brush with stone fill near edge of water.

US right: $\quad$ Yes

Do banks appear stable? -

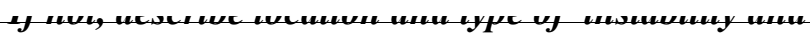

date of observatton.

$12 / 95$ noted no obstructions in channel.

Describe any obstructions in channel and date of observation. 


\section{Hydrology}

Drainage area $\frac{10.3}{\boldsymbol{m i}^{2}}$

Percentage of drainage area in physiographic provinces: (approximate)

Physiographic province/section

New England/Green Mountain
Percent of drainage area 100

Is drainage area considered rural or urban? Rural Describe any significant urbanization:

There are houses on the upstream right overbank area and both downstream overbank areas.

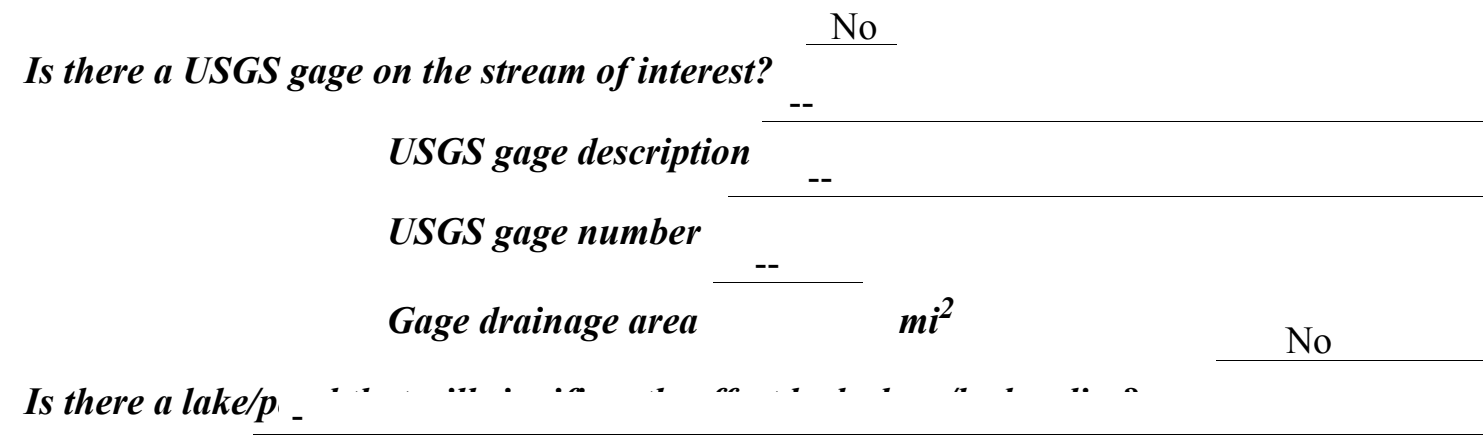

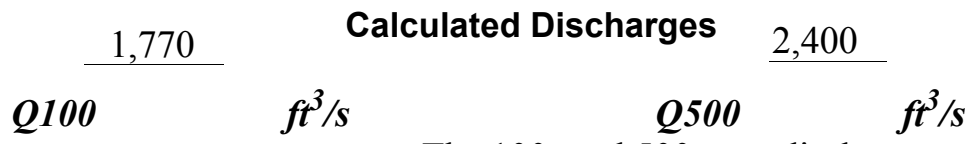

The 100- and 500-year discharges are based on a

drainage-area relationship [(10.3/7.3)exp 0.67] with estimates available from the VTAOT database for bridge number 98I in Ludlow (written communication 5/95). Bridge number 98I crosses Jewell Brook upstream of this site and has a drainage area of 7.3 square miles. The 100and 500-year discharge values are within the range of flood frequency curves computed by use of several empirical methods (Benson, 1962; Johnson and Tasker, 1974; FHWA, 1983; Potter, 1957a\&b; Talbot, 1887) 


\section{Description of the Water-Surface Profile Model (WSPRO) Analysis}

Datum for WSPRO analysis (USGS survey, sea level, VTAOT plans)

USGS survey

Datum tie between USGS survey and VTAOT plans

None

Description of reference marks used to determine USGS datum.

RM1 is a chiseled $\mathrm{X}$ on top of a concrete curb at the downstream end of the left abutment at the corner of the bridge deck

(elev. $500.59 \mathrm{ft}$, arbitrary survey datum). RM2 is a chiseled X on top of a concrete curb at the downstream end of the right abutment at the corner of the bridge deck (elev. $500.67 \mathrm{ft}$, arbitrary survey datum). RM3 is a nail placed 5 feet up from the base of a telephone pole located on the upstream right bank, $50 \mathrm{ft}$ from the right abutment and 75 $\mathrm{ft}$ upstream, on the corner of Andover St. and Pond St. (507.29 ft, arbitrary survey datum).

\section{Cross-Sections Used in WSPRO Analysis}

\begin{tabular}{cccl}
\hline${ }^{1}$ Cross-section & $\begin{array}{c}\text { Section } \\
\text { Reference } \\
\text { Distance } \\
\text { (SRD) in feet }\end{array}$ & $\begin{array}{c}{ }^{2} \text { Cross-section } \\
\text { development }\end{array}$ & \multicolumn{1}{c}{ Comments } \\
EXIT2 & -35 & 1 & $\begin{array}{l}\text { Exit section } \\
\text { Downstream Full-valley } \\
\text { section (Templated from } \\
\text { EXIT2) }\end{array}$ \\
BRIDG & 0 & 2 & $\begin{array}{l}\text { Bridge section } \\
\text { RDWAY }\end{array}$ \\
APPR2 & 0 & 1 & $\begin{array}{l}\text { Road Grade section } \\
\text { Modelled Approach sec- } \\
\text { tion (Templated from } \\
\text { APTEM) }\end{array}$ \\
APTEM & 47 & 2 & $\begin{array}{l}\text { Approach section as sur- } \\
\text { veyed (Used as a tem- } \\
\text { plate) }\end{array}$ \\
\hline
\end{tabular}

${ }^{1}$ For location of cross-sections see plan-view sketch included with Level I field form, Appendix E. For more detail on how cross-sections were developed see WSPRO input file. 


\section{Data and Assumptions Used in WSPRO Model}

Hydraulic analyses of the reach were done by use of the Federal Highway Administration's WSPRO step-backwater computer program (Shearman and others, 1986, and Shearman, 1990). The analyses reported herein reflect conditions existing at the site at the time of the study. Furthermore, in the development of the model it was necessary to assume no accumulation of debris or ice at the site. Results of the hydraulic model are presented in the Bridge Hydraulic Summary, appendix B, and figure 7.

Channel roughness factors (Manning's " $n$ ") used in the hydraulic model were estimated using field inspections at each cross section following the general guidelines described by Arcement and Schneider (1989). Final adjustments to the values were made during the modelling of the reach. Channel " $\mathrm{n}$ " values for the reach ranged from 0.040 to 0.070 , and overbank " $\mathrm{n}$ " values ranged from 0.045 to 0.050 .

Normal depth at the exit section (EXIT2) was assumed as the starting water surface. This depth was computed by use of the slope-conveyance method outlined in the user's manual for WSPRO (Shearman, 1990). The slope used was $0.017 \mathrm{ft} / \mathrm{ft}$ which was estimated from the appropriate topographic map (U.S. Geological Survey, 1971).

The surveyed approach section (APTEM) was moved along the approach channel slope $(0.008 \mathrm{ft} / \mathrm{ft})$ to establish the modelled approach section (APPR2), one bridge length upstream of the upstream face as recommended by Shearman and others (1986). This location also provides a consistent method for determining scour variables. 


\section{Bridge Hydraulics Summary}

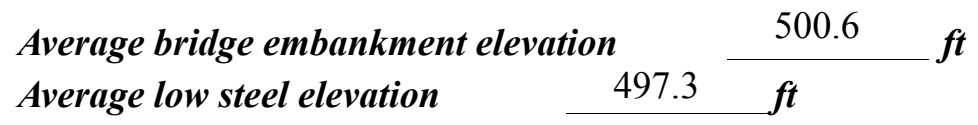

$$
\text { 100-year discharge } \quad 1,770 \quad \mathrm{ft}^{3} / \mathrm{s}
$$

Water-surface elevation in bridge opening $\quad 497.4 \quad f t$

Road overtopping? ___ No Discharge over road ___ - $\mathrm{ft}^{3} / \mathrm{s}$

\begin{tabular}{llll} 
Area of flow in bridge opening & $208 \quad \boldsymbol{f t}^{2}$ \\
\cline { 2 - 3 } Average velocity in bridge opening & 8.5 & $\boldsymbol{f t} / \mathrm{s}$
\end{tabular}

Maximum WSPRO tube velocity at bridge $\quad \begin{array}{lll}9.6 & \mathrm{tt} / \mathrm{s}\end{array}$

Water-surface elevation at Approach section with bridge 499.1

Water-surface elevation at Approach section without bridge $\quad \overline{497.8}$

Amount of backwater caused by bridge $\quad 1.3$ it

500-year discharge $\quad 2,400 \quad \mathrm{ft}^{3} / \mathrm{s}$

Water-surface elevation in bridge opening $497.4 \mathrm{ft}$

Road overtopping? ___ Yes Discharge over road __ $161 \quad \mathrm{ft}^{3} / \mathrm{s}$

Area of flow in bridge opening $\quad 208 \quad \boldsymbol{f t}^{2}$

Average velocity in bridge opening $10.8 \mathrm{ft} / \mathrm{s}$

Maximum WSPRO tube velocity at bridge 12.2 's

Water-surface elevation at Approach section with bridge $\quad 500.0$

Water-surface elevation at Approach section without bridge $\quad 498.9$

Amount of backwater caused by bridge $1.1, t$

Incipient overtopping discharge $\quad 1,660 \mathrm{ft}^{3} / \mathrm{s}$

Water-surface elevation in bridge opening $\quad 495.4 \quad$ t

Area of flow in bridge opening $\quad 147 \quad \mathrm{ft}^{2}$

Average velocity in bridge opening $\quad 11.3 \mathrm{ft} / \mathrm{s}$

Maximum WSPRO tube velocity at bridge $13.2 \mathrm{ft} / \mathrm{s}$

Water-surface elevation at Approach section with bridge

Water-surface elevation at Approach section without bridge

497.5

Amount of backwater caused by bridge N/A it 


\section{Scour Analysis Summary}

\section{Special Conditions or Assumptions Made in Scour Analysis}

Scour depths were computed using the general guidelines described in Hydraulic Engineering Circular 18 (Richardson and Davis, 1995). Scour depths were calculated assuming an infinite depth of erosive material and a homogeneous particle-size distribution. The results of the scour analyses for the 100- and 500-year discharges are presented in tables 1 and 2 and the scour depths are shown graphically in figure 8.

Contraction scour for the incipient roadway-overtopping discharge was computed by use of the Laursen clear-water contraction scour equation (Richardson and Davis, 1995, p. 32, equation 20a). The 100- and 500-year discharges resulted in an orifice flow solution. Contraction scour at bridges with orifice flow is best estimated by use of the Chang pressureflow scour equation (oral communication, J. Sterling Jones, October 4, 1996). Thus, for these discharges contraction scour was computed by use of the Chang pressure-flow scour equation (Richardson and Davis, 1995, p. 144-146). The streambed armoring depths computed suggest that armoring will not limit the depth of contraction scour.

For comparison, estimates of contraction scour also were computed for the discharges resulting in orifice flow by use of the Laursen clear-water contraction scour equation and the Umbrell pressure-flow equation (Richardson and Davis, 1995, p. 144). Results of these computations are presented in appendix F. Furthermore, for the 100-year discharge, which resulted in unsubmerged orifice flow, contraction scour was computed by substituting an estimate for the depth of flow at the downstream bridge face in the contraction scour equations. Results with respect to this substitution also are provided in appendix F.

Abutment scour was computed by use of the Froehlich equation (Richardson and Davis, 1995, p. 48, equation 28). Variables for the Froehlich equation include the Froude number of the flow approaching the embankments, the length of the embankment blocking flow, and the depth of flow approaching the embankment less any roadway overtopping. 


\section{Scour Results}

100-yr discharge 500-yr discharge

Contraction scour:

(Scour depths in feet)

Main channel

Live-bed scour

Clear-water scour

Depth to armoring

Left overbank

Right overbank

Local scour:

Abutment scour

Left abutment

11.9

13.8

11.0

7.0

7.3-

$6.2-$

Right abutment

Pier scour

Pier 1

Pier 2

Pier 3

Abutments:

Left abutment

Right abutment

Piers:

Pier 1

Pier 2

\section{Riprap Sizing}

Incipient overtopping 100-yrdischarge 500-yrdischarge discharge

1.2

( $D_{50}$ in feet)

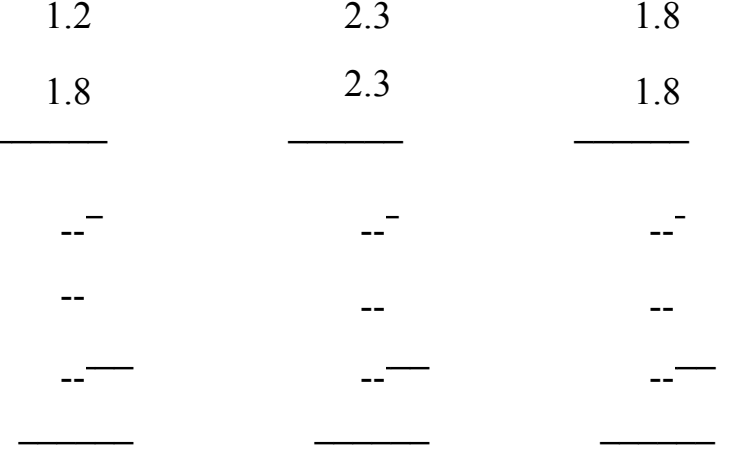




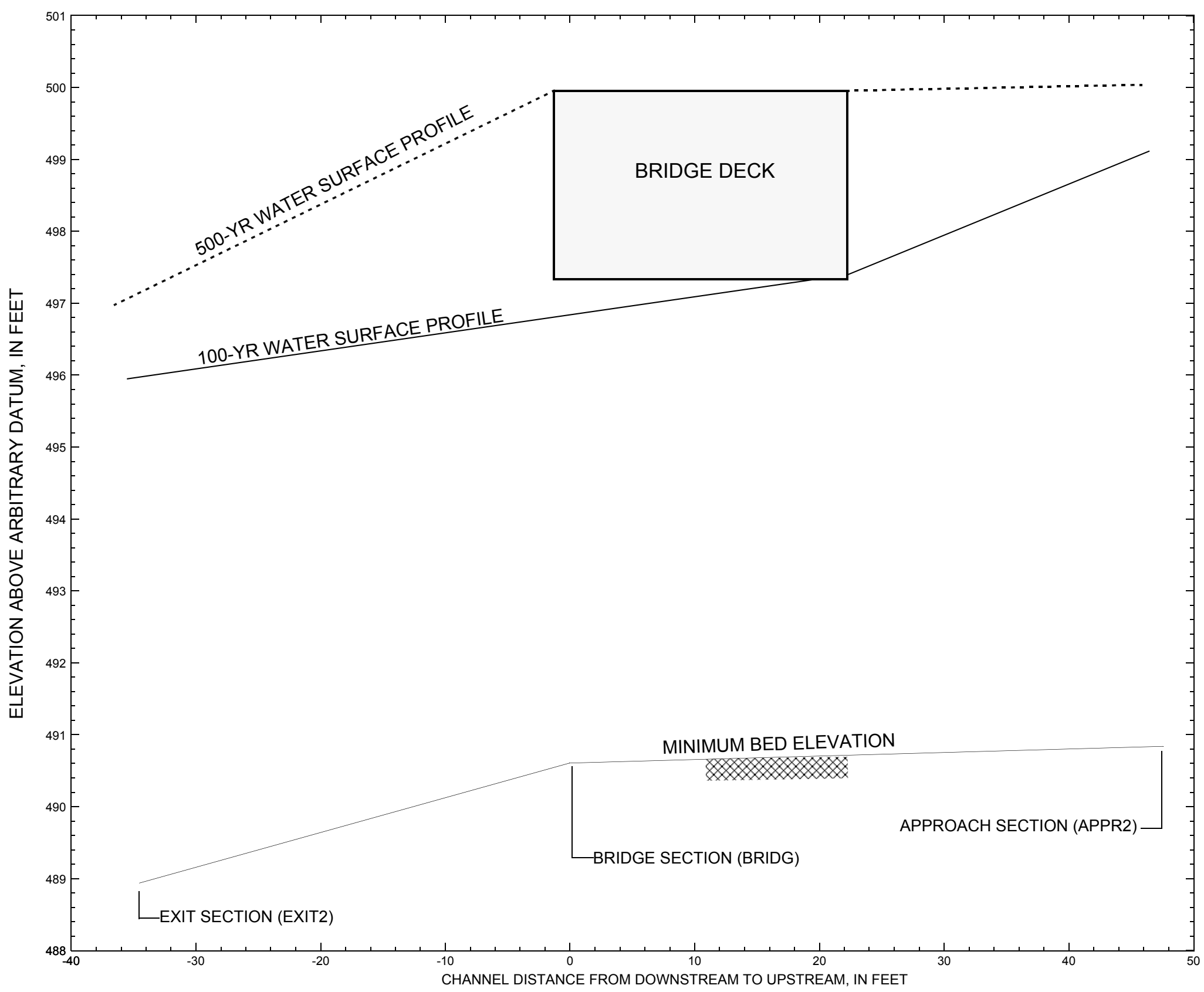

Figure 7. Water-surface profiles for the 100- and 500-yr discharges at structure LUDLTH03560054 on Town Highway 356, crossing Jewell Brook, Ludlow, Vermont. 


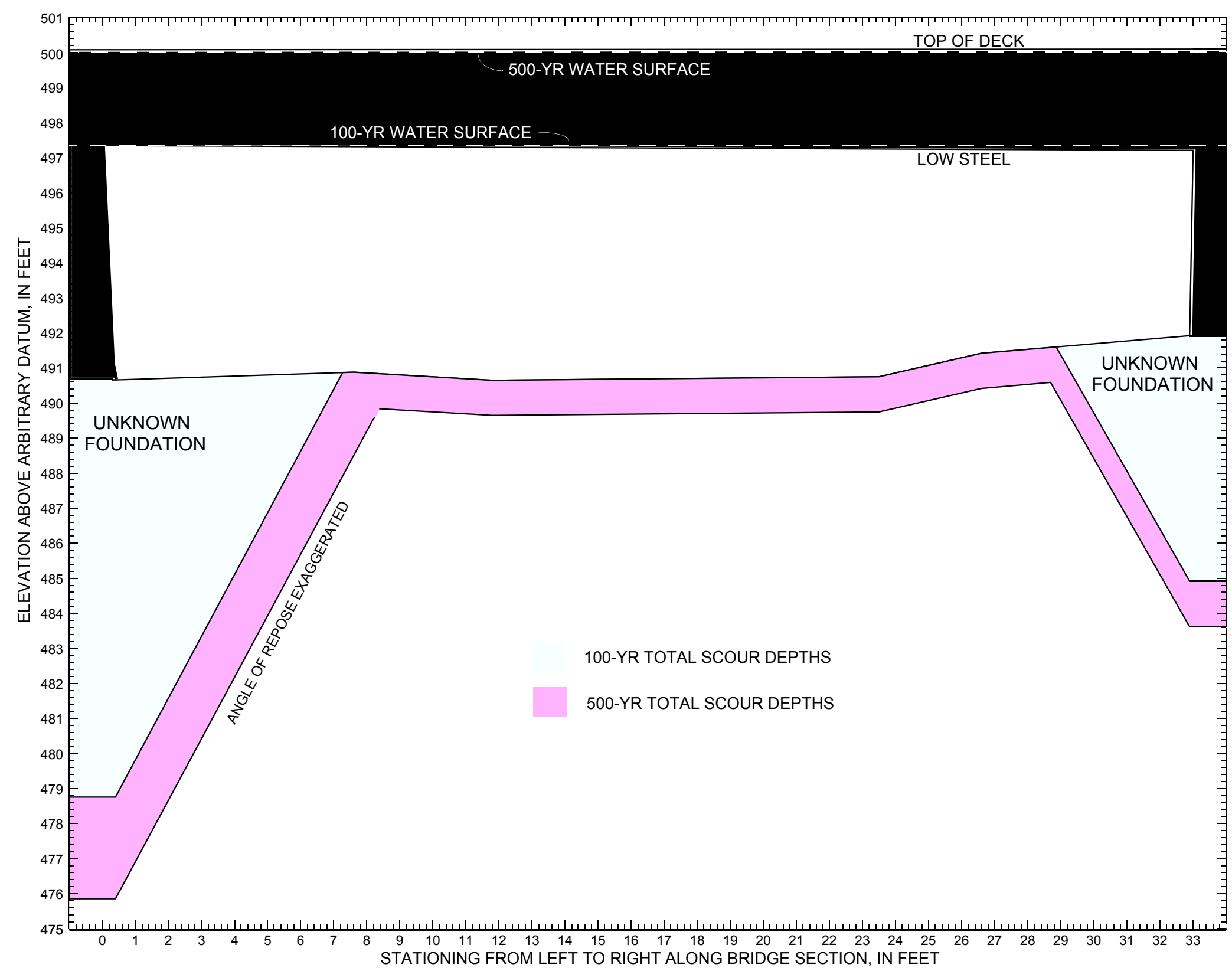

Figure 8. Scour elevations for the 100- and 500-yr discharges at structure LUDLTH03560054 on Town Highway 356, crossing Jewell Brook, Ludlow, Vermont. 


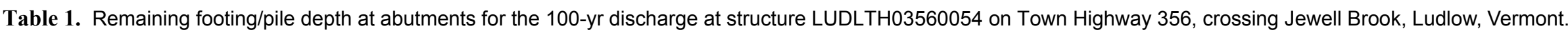
[VTAOT, Vermont Agency of Transportation; --, no data]

\begin{tabular}{|c|c|c|c|c|c|c|c|c|c|c|c|}
\hline Description & Station $^{1}$ & $\begin{array}{l}\text { VTAOT } \\
\text { minimum } \\
\text { low-chord } \\
\text { elevation } \\
\text { (feet) }\end{array}$ & $\begin{array}{c}\text { Surveyed } \\
\text { minimum } \\
\text { low-chord } \\
\text { elevation } \\
\text { (feet) }\end{array}$ & $\begin{array}{c}\text { Bottom of } \\
\text { footing } \\
\text { elevation } \\
\text { (feet) }\end{array}$ & $\begin{array}{c}\text { Channel } \\
\text { elevation at } \\
\text { abutment/ } \\
\text { pier }^{2} \\
\text { (feet) }\end{array}$ & $\begin{array}{l}\text { Contraction } \\
\text { scour depth } \\
\text { (feet) }\end{array}$ & $\begin{array}{l}\text { Abutment } \\
\text { scour } \\
\text { depth } \\
\text { (feet) }\end{array}$ & $\begin{array}{l}\text { Pier } \\
\text { scour } \\
\text { depth } \\
\text { (feet) }\end{array}$ & $\begin{array}{l}\text { Depth of } \\
\text { total scour } \\
\text { (feet) }\end{array}$ & $\begin{array}{c}\text { Elevation of } \\
\text { scour }^{2} \\
\text { (feet) }\end{array}$ & $\begin{array}{c}\text { Remaining } \\
\text { footing/pile } \\
\text { depth } \\
\text { (feet) }\end{array}$ \\
\hline \multicolumn{12}{|c|}{100 -yr discharge is 1,770 cubic-feet per second } \\
\hline Left abutment & 0.0 & --- & 497.3 & -- & 490.7 & 0 & 11.9 & -- & 11.9 & 478.8 & -- \\
\hline Right abutment & 33.0 & --- & 497.2 & -- & 491.9 & 0 & 7.0 & -- & 7.0 & 484.9 & -- \\
\hline
\end{tabular}

1.Measured along the face of the most constricting side of the bridge.

2.Arbitrary datum for this study.

Table 2. Remaining footing/pile depth at abutments for the 500-yr discharge at structure LUDLTH03560054 on Town Highway 356, crossing Jewell Brook, Ludlow, Vermont. [VTAOT, Vermont Agency of Transportation; --, no data]

\begin{tabular}{|c|c|c|c|c|c|c|c|c|c|c|c|}
\hline Description & Station $^{1}$ & $\begin{array}{l}\text { VTAOT } \\
\text { minimum } \\
\text { low-chord } \\
\text { elevation } \\
\text { (feet) }\end{array}$ & $\begin{array}{l}\text { Surveyed } \\
\text { minimum } \\
\text { low-chord } \\
\text { elevation } \\
\text { (feet) }\end{array}$ & $\begin{array}{c}\text { Bottom of } \\
\text { footing } \\
\text { elevation } \\
\text { (feet) }\end{array}$ & $\begin{array}{c}\text { Channel } \\
\text { elevation at } \\
\text { abutment/ } \\
\text { pier }^{2} \\
\text { (feet) }\end{array}$ & $\begin{array}{l}\text { Contraction } \\
\text { scour depth } \\
\text { (feet) }\end{array}$ & $\begin{array}{l}\text { Abutment } \\
\text { scour } \\
\text { depth } \\
\text { (feet) }\end{array}$ & $\begin{array}{l}\text { Pier } \\
\text { scour } \\
\text { depth } \\
\text { (feet) }\end{array}$ & $\begin{array}{l}\text { Depth of } \\
\text { total scour } \\
\text { (feet) }\end{array}$ & $\begin{array}{c}\text { Elevation of } \\
\text { scour }^{2} \\
\text { (feet) }\end{array}$ & $\begin{array}{c}\text { Remaining } \\
\text { footing/pile } \\
\text { depth } \\
\text { (feet) }\end{array}$ \\
\hline \multicolumn{12}{|c|}{500 -yr discharge is 2,400 cubic-feet per second } \\
\hline Left abutment & 0.0 & --- & 497.3 & -- & 490.7 & 1.0 & 13.8 & -- & 14.8 & 475.9 & -- \\
\hline Right abutment & 33.0 & --- & 497.2 & -- & 491.9 & 1.0 & 7.3 & -- & 8.3 & 483.6 & -- \\
\hline
\end{tabular}

1.Measured along the face of the most constricting side of the bridge.

2.Arbitrary datum for this study. 


\section{SELECTED REFERENCES}

Arcement, G.J., Jr., and Schneider, V.R., 1989, Guide for selecting Manning's roughness coefficients for natural channels and flood plains: U.S. Geological Survey Water-Supply Paper 2339, 38 p.

Barnes, H.H., Jr., 1967, Roughness characteristics of natural channels: U.S. Geological Survey Water-Supply Paper 1849,213 p.

Benson, M. A., 1962, Factors Influencing the Occurrence of Floods in a Humid Region of Diverse Terrain: U.S. Geological Survey WaterSupply Paper 1580-B, 64 p.

Brown, S.A. and Clyde, E.S., 1989, Design of riprap revetment: Federal Highway Administration Hydraulic Engineering Circular No. 11, Publication FHWA-IP-89-016, 156 p.

Federal Highway Administration, 1983, Runoff estimates for small watersheds and development of sound design: Federal Highway Administration Report FHWA-RD-77-158.

Federal Highway Administration, 1993, Stream Stability and Scour at Highway Bridges: Participant Workbook: Federal Highway Administration Report FHWA-HI-91-011.

Froehlich, D.C., 1989, Local scour at bridge abutments in Ports, M.A., ed., Hydraulic Engineering--Proceedings of the 1989 National Conference on Hydraulic Engineering: New York, American Society of Civil Engineers, p. 13-18.

Hayes, D.C.,1993, Site selection and collection of bridge-scour data in Delaware, Maryland, and Virginia: U.S. Geological Survey WaterResources Investigation Report 93-4017, 23 p.

Interagency Advisory Committee on Water Data, 1982, Guidelines for determining flood flow frequency: U.S. Geological Survey, Bulletin 17B of the Hydrology Subcommittee, 190 p.

Johnson, C.G. and Tasker, G.D.,1974, Progress report on flood magnitude and frequency of Vermont streams: U.S. Geological Survey OpenFile Report 74-130, 37 p.

Lagasse, P.F., Schall, J.D., Johnson, F., Richardson, E.V., Chang, F., 1995, Stream Stability at Highway Structures: Federal Highway Administration Hydraulic Engineering Circular No. 20, Publication FHWA-IP-90-014, 144 p.

Laursen, E.M., 1960, Scour at bridge crossings: Journal of the Hydraulics Division, American Society of Civil Engineers, v. 86, no. HY2, p. 39-53.

Potter, W. D., 1957a, Peak rates of runoff in the Adirondack, White Mountains, and Maine woods area, Bureau of Public Roads

Potter, W. D., 1957b, Peak rates of runoff in the New England Hill and Lowland area, Bureau of Public Roads

Richardson, E.V. and Davis, S.R., 1995, Evaluating scour at bridges: Federal Highway Administration Hydraulic Engineering Circular No. 18, Publication FHWA-IP-90-017, 204 p.

Richardson, E.V., Simons, D.B., and Julien, P.Y., 1990, Highways in the river environment: Federal Highway Administration Publication FHWA-HI-90-016.

Ritter, D.F., 1984, Process Geomorphology: W.C. Brown Co., Debuque, Iowa, 603 p.

Shearman, J.O., 1990, User's manual for WSPRO--a computer model for water surface profile computations: Federal Highway Administration Publication FHWA-IP-89-027, 187 p.

Shearman, J.O., Kirby, W.H., Schneider, V.R., and Flippo, H.N., 1986, Bridge waterways analysis model; research report: Federal Highway Administration Publication FHWA-RD-86-108, 112 p.

Talbot, A.N., 1887, The determination of water-way for bridges and culverts.

U.S. Geological Survey, 1971, Ludlow, Vermont 7.5 Minute Series quadrangle map: U.S. Geological Survey Topographic Maps, Scale 1:24,000. 


\section{APPENDIX A:}

WSPRO INPUT FILE 


\section{WSPRO INPUT FILE}

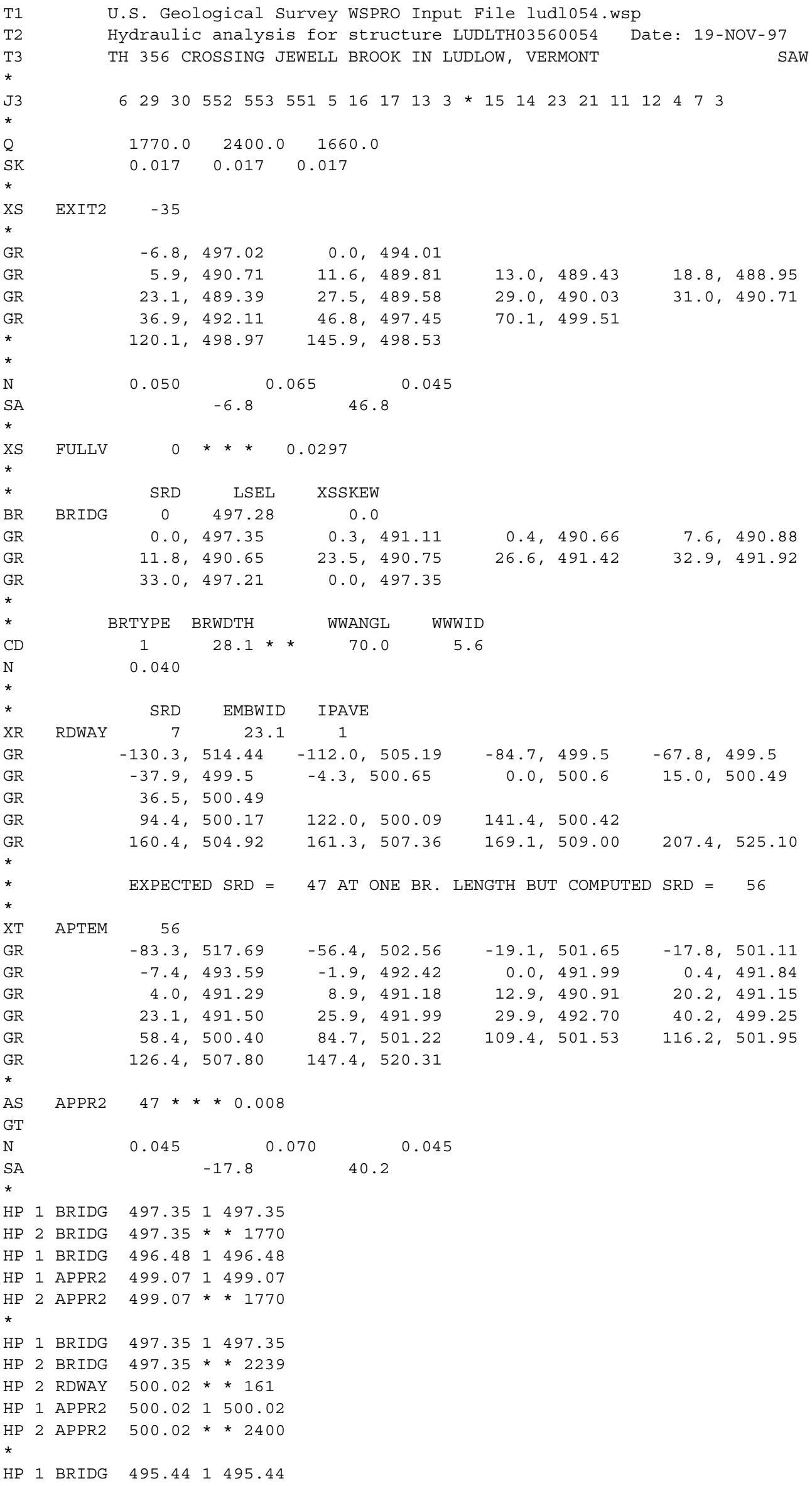




\section{APPENDIX B: \\ WSPRO OUTPUT FILE}


WSPRO OUTPUT FILE

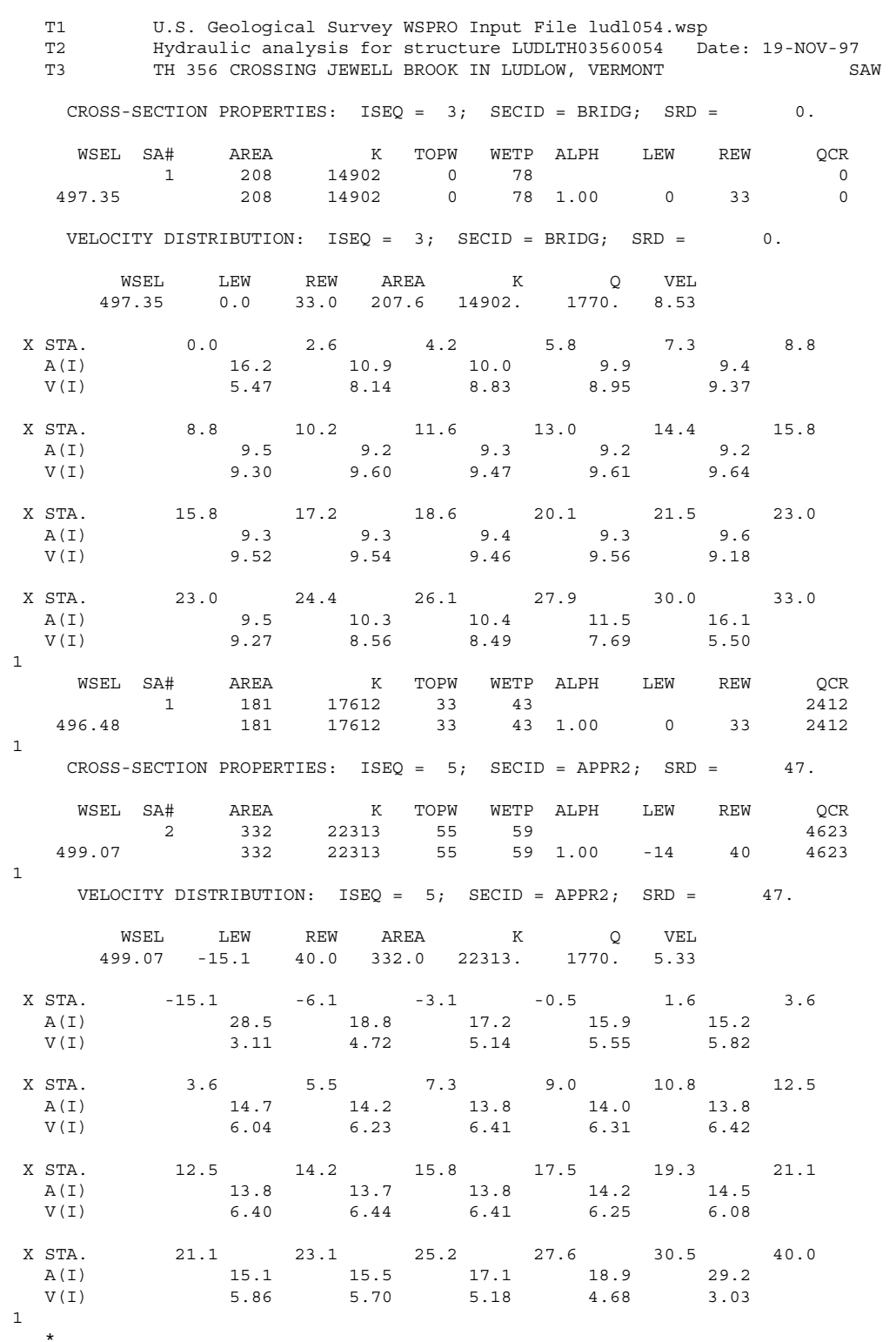


WSPRO OUTPUT FILE (continued)

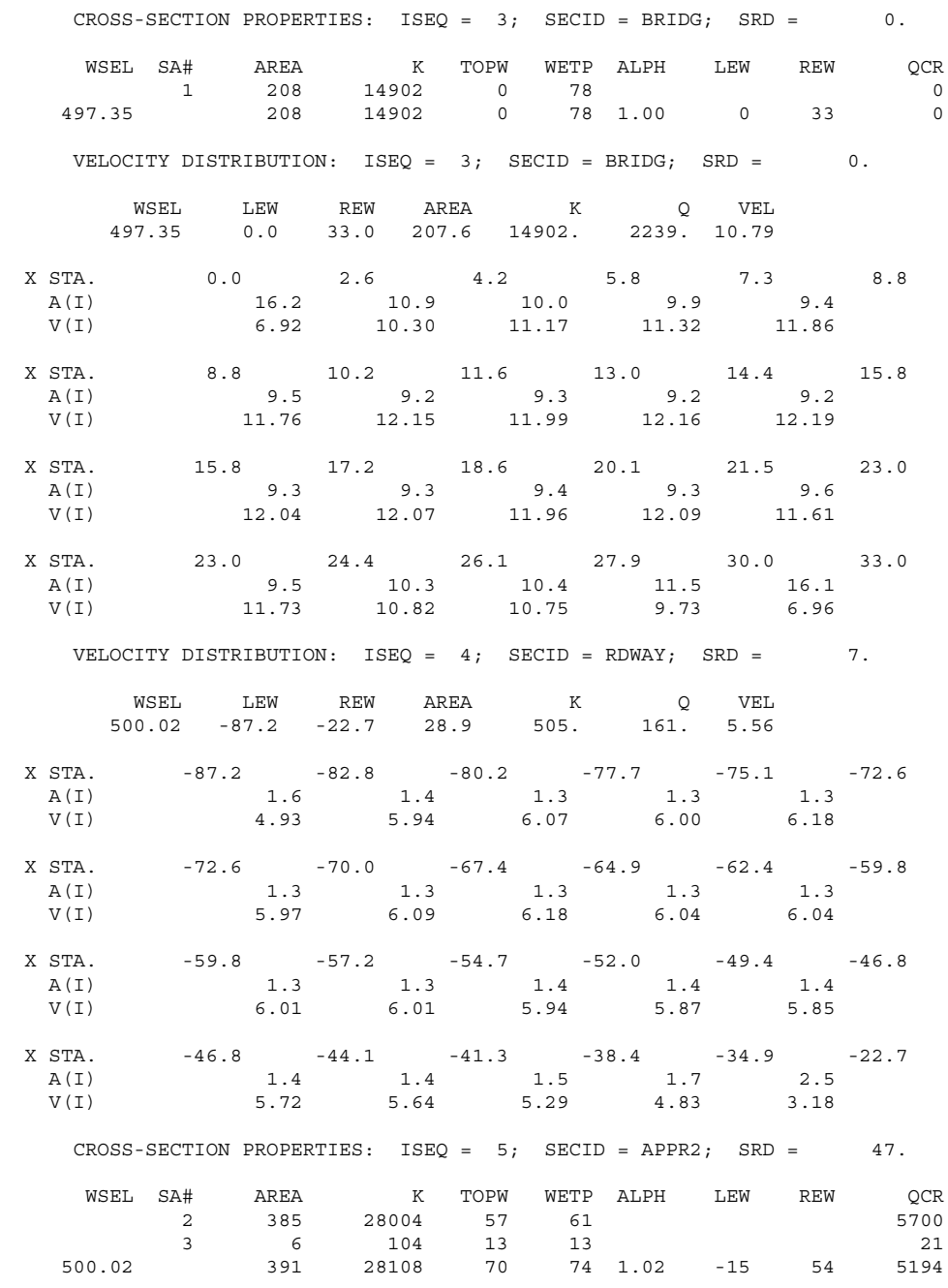

VELOCITY DISTRIBUTION $:$ ISEQ $=5 ; \quad$ SECID $=$ APPR2 $; \quad$ SRD $=47$.

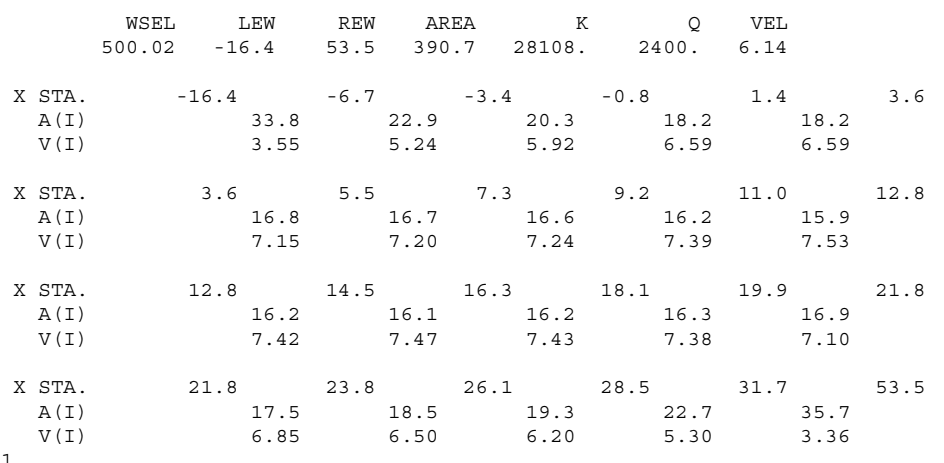


WSPRO OUTPUT FILE (continued)

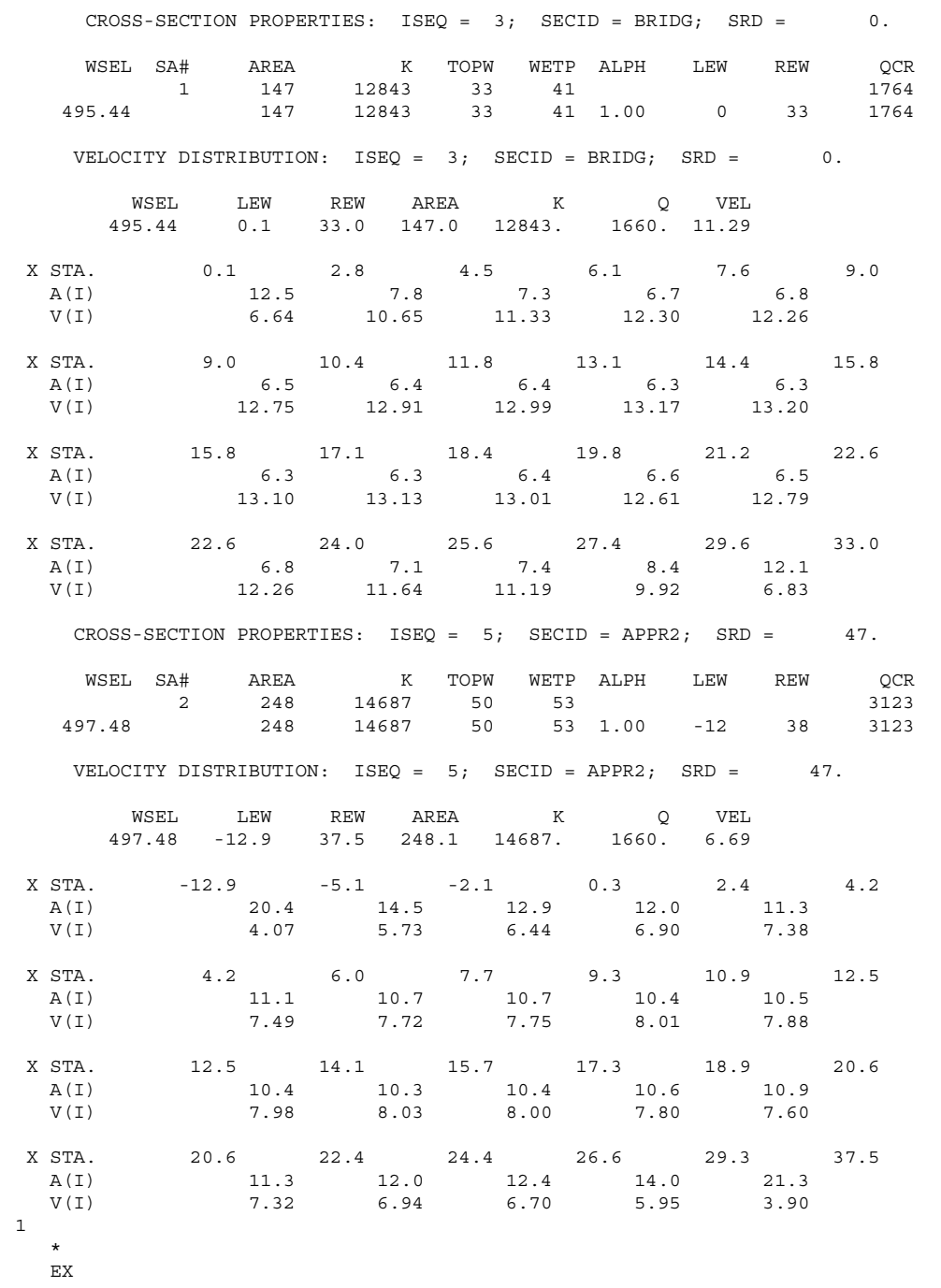


WSPRO OUTPUT FILE (continued)

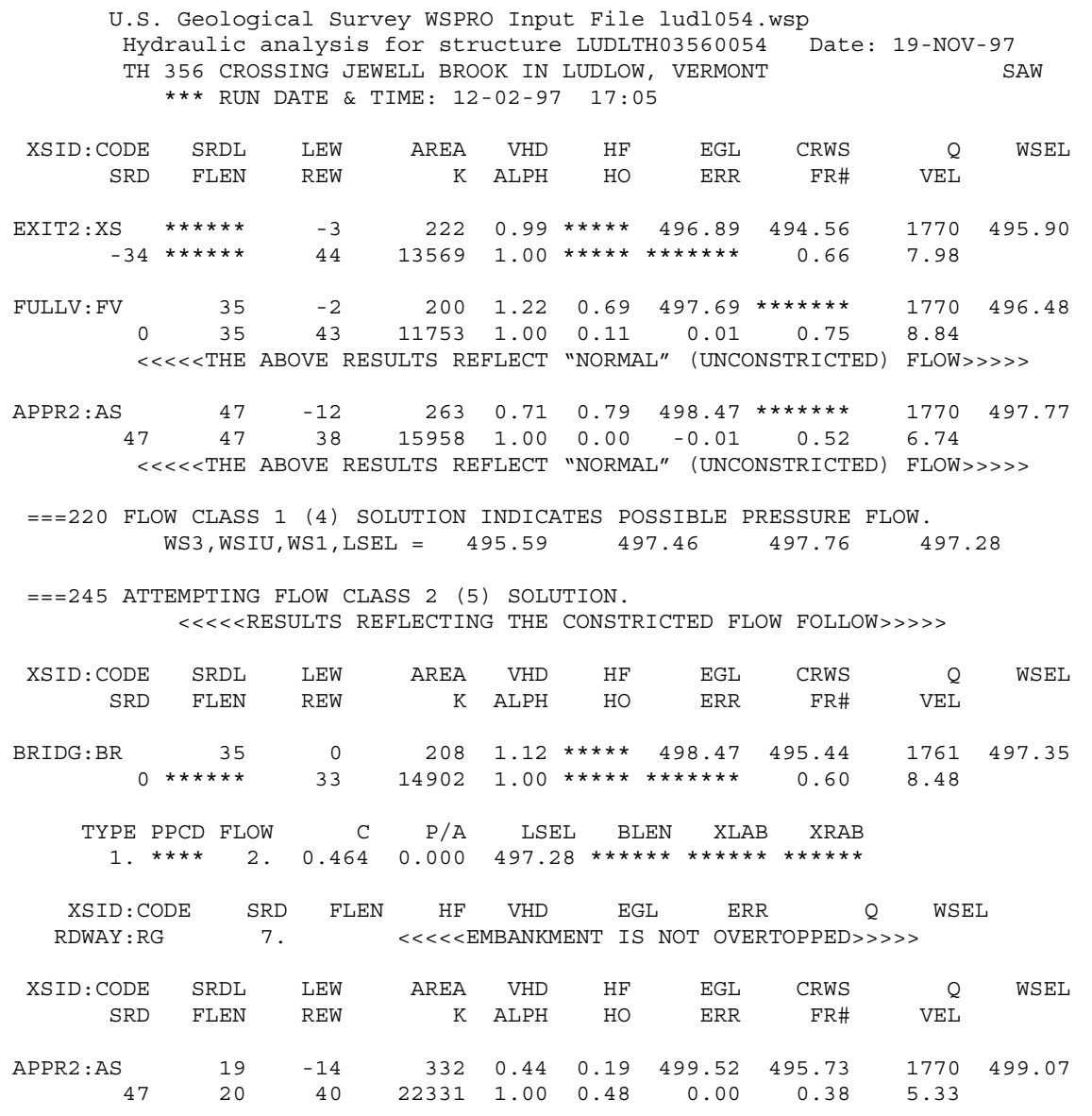

FIRST USER DEFINED TABLE.

$\begin{array}{lrrrrrrrr}\text { XSID : CODE } & \text { SRD } & \text { LEW } & \text { REW } & \text { Q } & \text { K } & \text { AREA } & \text { VEL } & \text { WSEL } \\ \text { EXIT2: XS } & -35 . & -4 . & 44 . & 1770 . & 13569 . & 222 . & 7.98 & 495.90 \\ \text { FULLV : FV } & 0 . & -3 . & 43 . & 1770 . & 11753 . & 200 . & 8.84 & 496.48 \\ \text { BRIDG : BR } & 0 . & 0 . & 33 . & 1761 . & 14902 . & 208 . & 8.48 & 497.35 \\ \text { RDWAY : RG } & 7 . * * * * * * * * * * * * & 0 . * * * * * * * * & 0 . & 1.00 * * * * * * * \\ \text { APPR2 : AS } & 47 . & -15 . & 40 . & 1770 . & 22331 . & 332 . & 5.33 & 499.07\end{array}$

SECOND USER DEFINED TABLE.

$\begin{array}{lrrrrrrrrr}\text { XSID :CODE } & \text { CRWS } & \text { FR\# } & \text { YMIN } & \text { YMAX } & \text { HF } & \text { HO } & \text { VHD } & \text { EGL } & \text { WSEL } \\ \text { EXIT2:XS } & 494.56 & 0.66 & 488.95 & 499.51 * * * * * * * * * * * & 0.99 & 496.89 & 495.90 \\ \text { FULLV:FV } & * * * * * * * & 0.75 & 489.99 & 500.55 & 0.69 & 0.11 & 1.22 & 497.69 & 496.48 \\ \text { BRIDG : BR } & 495.44 & 0.60 & 490.65 & 497.35 * * * * * * * * * * * & 1.12 & 498.47 & 497.35 \\ \text { RDWAY:RG } & * * * * * * * * * * * * * * & 499.50 & 525.10 * * * * * * * * * * * & 0.31 & 500.37 * * * * * * * \\ \text { APPR2:AS } & 495.73 & 0.38 & 490.84 & 520.24 & 0.19 & 0.48 & 0.44 & 499.52 & 499.07\end{array}$


WSPRO OUTPUT FILE (continued)

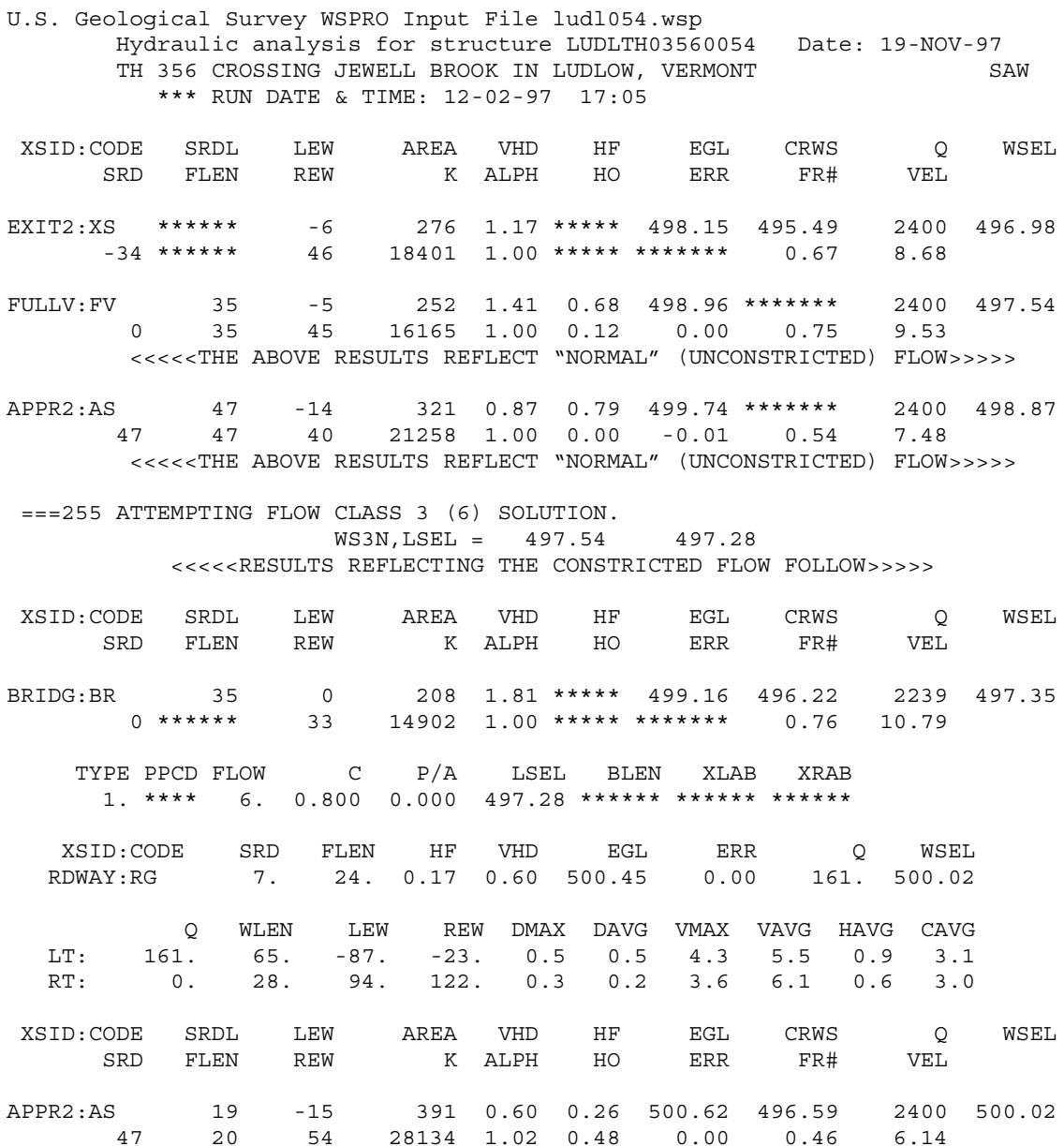




\section{WSPRO OUTPUT FILE (continued)}

U.S. Geological Survey WSPRO Input File ludl054.wsp Hydraulic analysis for structure LUDLTH03560054

TH 356 CROSSING JEWELL BROOK IN LUDLOW, VERMONT

Date: 19-NOV-97

*** RUN DATE \& TIME: 12-02-97 17:05

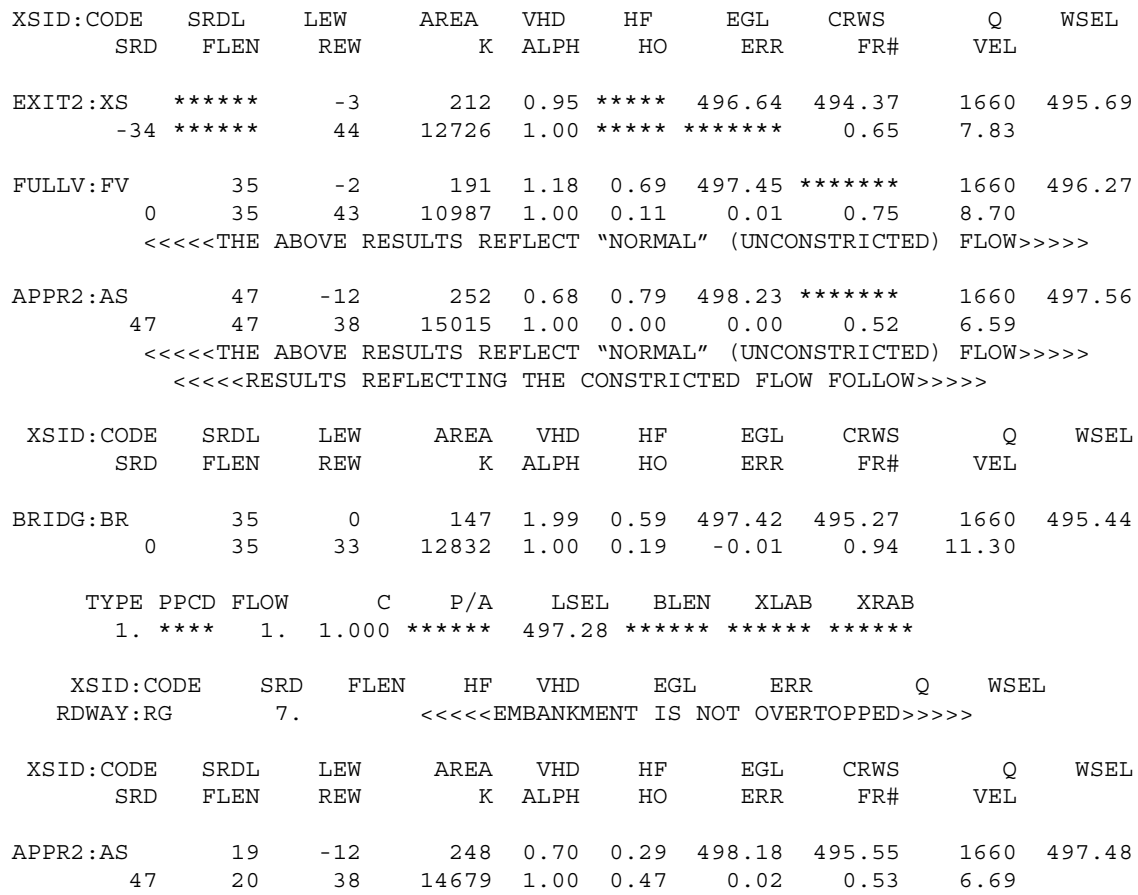

FIRST USER DEFINED TABLE.

\begin{tabular}{|c|c|c|c|c|c|c|c|c|}
\hline XSID : CODE & SRD & LEW & REW & 0 & $\mathrm{~K}$ & AREA & VEL & WSEI \\
\hline EXIT2:XS & -35 & -4 & 44 . & 1660 . & 12726 . & 212 . & 7.83 & 495.69 \\
\hline FULLV : FV & 0 . & -3 & 43. & 1660. & 10987. & 191. & 8.70 & 496.27 \\
\hline BRIDG : BR & 0 . & 0 . & 33. & 1660. & 12832 . & 147 . & 11.30 & 495.44 \\
\hline RDWAY : RG & \multicolumn{3}{|c|}{ 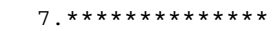 } & \multicolumn{3}{|c|}{ 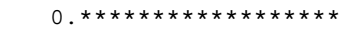 } & \multicolumn{2}{|c|}{$1.00 * * * \star * * * *$} \\
\hline APPR 2 : AS & 47. & -13 & 38. & 1660. & 14679 . & 248 & 6.69 & 497.48 \\
\hline
\end{tabular}

SECOND USER DEFINED TABLE.

\begin{tabular}{|c|c|c|c|c|c|c|c|c|c|}
\hline XSID : CODE & CRWS & FR\# & YMIN & YMAX & $\mathrm{HF}$ & $\mathrm{HO}$ & VHD & EGL & WSEL \\
\hline EXIT2:XS & 494.37 & 0.65 & 488.95 & $499.51 *$ & 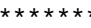 & $* \star \star \star \star *$ & 0.95 & 496.64 & 495.69 \\
\hline FULLV : FV & 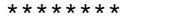 & 0.75 & 489.99 & 500.55 & 0.69 & 0.11 & 1.18 & 497.45 & 496.27 \\
\hline BRIDG : BR & 495.27 & 0.94 & 490.65 & 497.35 & 0.59 & 0.19 & 1.99 & 497.42 & 495.44 \\
\hline RDWAY : RG & $* \star * * \star * * * * * * *$ & 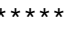 & 499.50 & 525.10 * & 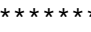 & 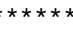 & $\star * \star * * *$ & 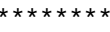 & 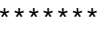 \\
\hline APPR2 : AS & 495.55 & 0.53 & 490.84 & 520.24 & 0.29 & 0.47 & 0.70 & 498.18 & 497.48 \\
\hline & & & & & & & & & \\
\hline 117 & WSPRU & & & & & & & & \\
\hline
\end{tabular}


APPENDIX C:

BED-MATERIAL PARTICLE-SIZE DISTRIBUTION 


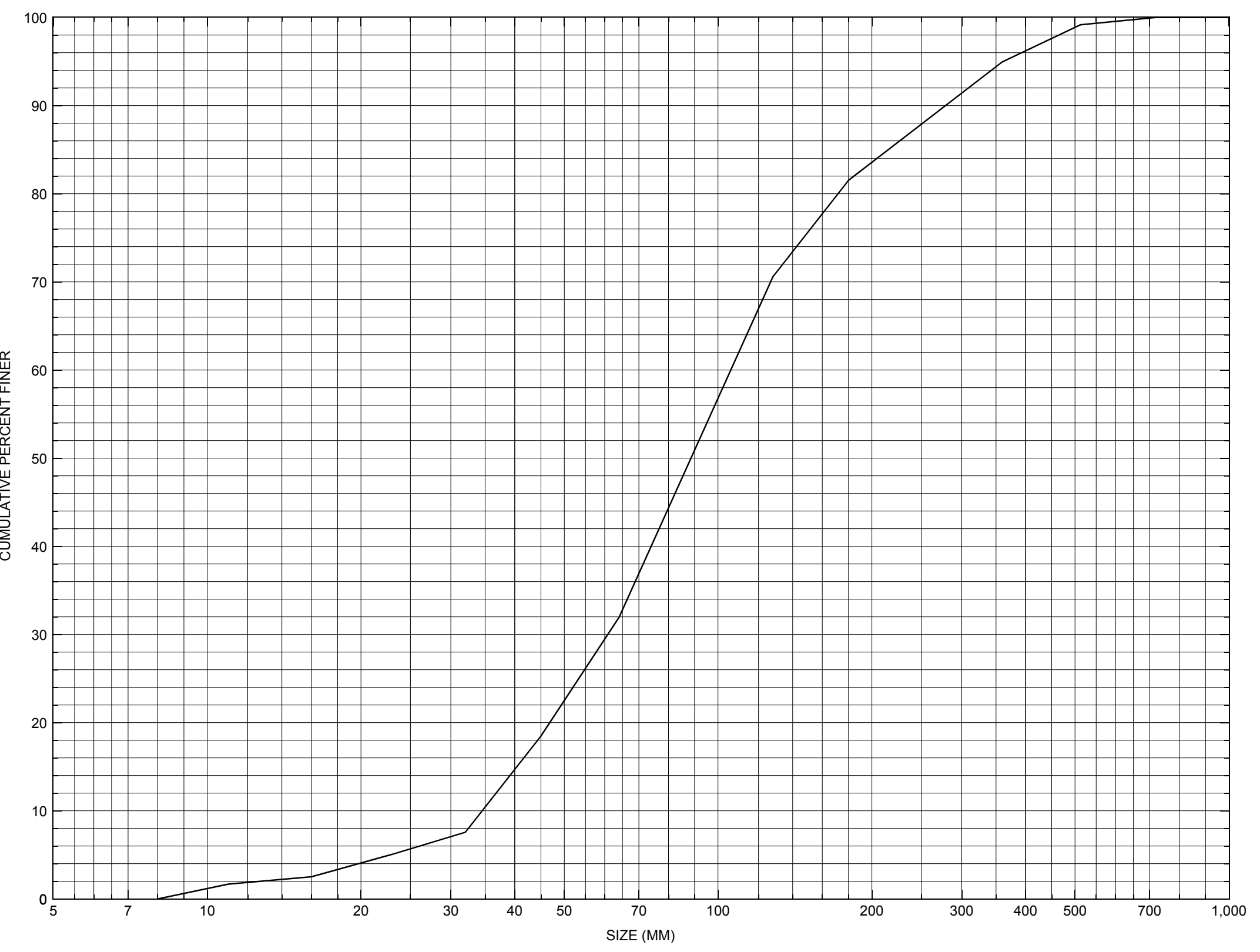

Appendix C. Bed material particle-size distribution for a pebble count in the channel approach of structure LUDLTH03560054, in Ludlow, Vermont. 


\section{APPENDIX D: \\ HISTORICAL DATA FORM}




\section{Structure Number LUDLTH03560054}

\section{General Location Descriptive}

Data collected by (First Initial, Full last name) $\mathbf{E}$. BOEHMLER

Date $(M M / D D / Y Y) \_\mathbf{0 3} / \underline{\mathbf{2 0}} / \underline{\mathbf{9 5}}$

Highway District Number $(I-2 ; n n) \underline{\mathbf{0 3}}$

Town (FIPS place code; I - 4; nnnnn) $\mathbf{4 1 2 0 0}$

Waterway ( $($ - 6) JEWELL BROOK

Route Number $\underline{\text { TH356 }}$

Topographic Map Ludlow

Latitude (I - 16; nnnn.n) $\mathbf{4 3 2 3 6}$
County (FIPS county code; I - 3; nnn)

Mile marker (I - 11; nnn.nnn) $\mathbf{0 0 0 0 0 0}$

Road Name (I - 7): -

Vicinity (I - 9)

Hydrologic Unit Code: $\mathbf{0 1 0 8 0 1 0 6}$

Longitude (i - 17; nnnnn.n) $\mathbf{7 2 4 2 3}$

\section{Select Federal Inventory Codes}

FHWA Structure Number (I - 8) 10141000541410

Maintenance responsibility $(I-21 ; n n) \quad \mathbf{0 3}$

Year built (I - 27; YYYY) 1937

Average daily traffic, ADT (I - 29; nnnnnn) 000600

Year of ADT (I - 30; YY) $\mathbf{9 3}$

Opening skew to Roadway $(I-34 ; n n) \quad 10$

Operational status $(I-41 ; X) \quad \mathbf{A}$

Structure type (I - 43; nnn) $\mathbf{3 0 2}$

Approach span structure type $(I-44 ; n n n) \quad \mathbf{0 0 0}$

Number of spans (I - 45; nnn) $\mathbf{0 0 1}$

Number of approach spans (I - 46; nnnn) $\mathbf{0 0 0 0}$

Comments:

The structural inspection report of 6/14/93 indicates the structure is a steel stringer type bridge with a concrete deck. The abutment walls and wingwalls are reported as concrete faced "laid-up" stone walls. Overall the abutment and wingwall concrete has surface spalling and random cracking. One of the right abutment's wingwalls is noted as having a settlement crack. There also is a settlement crack on the right abutment wall and on the left abutment wall. Yet another is noted as a diagonal crack in one of the wingwalls of the left abutment and may have resulted in a small section of concrete facing spalling off the wall at the bottom right corner. (Continued, page 32)
Maximum span length (I - 48; nnnn) $\underline{\mathbf{0 0 3 7}}$

Structure length (I - 49; nnnnnn) $\underline{000041}$

Deck Width (I - 52; nn.n) 231

Channel \& Protection $(I-61 ; n) \underline{5}$

Waterway adequacy $(I-71 ; n) \underline{6}$

Underwater Inspection Frequency $(I-92 B ; X Y Y) \_$N

Year Reconstructed (I - 106) $\mathbf{0 0 0 0}$

Clear span (nnn.n ft) _

Vertical clearance from streambed (nnn.n ft) $\underline{\mathbf{0 0 6 . 0}}$

Waterway of full opening (nnn.n $\left.\mathrm{ft}^{2}\right)$ 


\section{Bridge Hydrologic Data}

Is there hydrologic data available? $\underline{\mathbf{N}}$ if No, type ctrl-n $h \quad$ VTAOT Drainage area $\left(m i^{2}\right)$ : -

Terrain character:

Stream character \& type: -

Streambed material:

Discharge Data (cfs):

$$
\begin{aligned}
& Q_{2.33}- \\
& Q_{50}-
\end{aligned}
$$

Record flood date $(M M / D D / Y Y)$ :

Estimated Discharge (cfs): Ice conditions (Heavy, Moderate, Light) : -

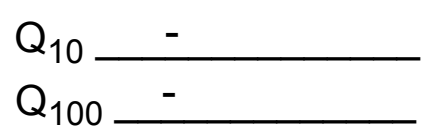

$$
\begin{aligned}
& Q_{25}- \\
& Q_{500}-
\end{aligned}
$$

Water surface elevation $(f t):-$

The stage increases to maximum highwater elevation (Rapidly, Not rapidly):

The stream response is (Flashy, Not flashy):

Describe any significant site conditions upstream or downstream that may influence the stream's stage: -

Watershed storage area (in percent): _ _ \%

The watershed storage area is: - (1-mainly at the headwaters; 2- uniformly distributed; 3-immediatly upstream oi the site)

Water Surface Elevation Estimates for Existing Structure:

\begin{tabular}{|l|l|l|l|l|l|}
\hline Peak discharge frequency & $Q_{2.33}$ & $Q_{10}$ & $Q_{25}$ & $Q_{50}$ & $Q_{100}$ \\
Water surface elevation (ft)) & - & - & - & - & - \\
Velocity (ft/sec) & - & - & - & - & - \\
\hline
\end{tabular}

Long term stream bed changes: -

Is the roadway overtopped below the $\mathrm{Q}_{100}$ ? (Yes, No, Unknown): $\mathbf{U}$ Frequency: Relief Elevation (ft): Discharge over roadway at $Q_{100}\left(f^{3} / \mathrm{sec}\right)$ :

Are there other structures nearby? (Yes, No, Unknown): $\underline{\mathbf{U}}$ Upstream distance (miles): Town: If No or Unknown, type ctrl-n os Highway No. : Structure No. : Year Built:

Clear span (ft): Clear Height $(f t)$ : Full Waterway $\left(f^{2}\right)$ : 
Downstream distance (miles): Town: Year Built:

Highway No. : Structure No. : Structure Type:

Clear span (ft): Clear Height $(f t)$ :

Full Waterway $\left(f^{2}\right)$ :

Comments:

Some natural stone fill protection is noted as visible along the upstream and downstream banks. The report indicates no footings were seen at the surface but noted some voids where the left abutment wall has been undermined with scour measured at 1 to 1.5 feet in the channel along the abutment.

\section{USGS Watershed Data}

Watershed Hydrographic Data Drainage area $(D A) \underline{10.31} \mathrm{mi}^{2}$

Watershed storage (ST) 0.7

Bridge site elevation 1020 $\mathrm{ft}$ $\%$

Main channel length 4.57 mi $10 \%$ channel length elevation $\mathbf{1 0 8 0}$ $\mathrm{ft} \quad 85 \%$ channel length elevation $\mathrm{ft}$

Main channel slope $(S)$ (S) 327.13 $\mathrm{ft} / \mathrm{mi}$

Watershed Precipitation Data

Average site precipitation in Average headwater precipitation in

Maximum 2yr-24hr precipitation event $(124,2)$ in

Average seasonal snowfall (Sn) $\mathrm{ft}$ 


\section{Bridge Plan Data}

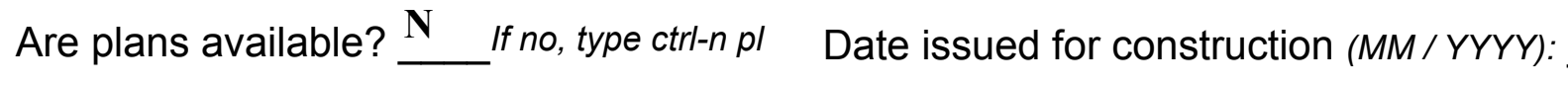

Project Number

Minimum channel bed elevation:

Low superstructure elevation: USLAB DSLAB USRAB DSRAB Benchmark location description:

NO BENCHMARK INFORMATION

Reference Point (MSL, Arbitrary, Other): Datum (NAD27, NAD83, Other):

Foundation Type: 4

If 1 : Footing Thickness

If 2: Pile Type:

If 3: Footing bottom elevation:

Is boring information available? $\mathbf{N}$

Foundation Material Type: $\mathbf{3}$

(1-Spreadfooting; 2-Pile; 3- Gravity; 4-Unknown)

Footing bottom elevation: -

Briefly describe material at foundation bottom elevation or around piles:

NO FOUNDATION MATERIAL INFORMATION

Comments:

NO PLANS. 


\section{Cross-sectional Data}

Is cross-sectional data available? Yes If no, type ctrl-n xs

Source (FEMA, VTAOT, Other)? VTAOT

The elevation and station coordinates are in feet. The sketch that the low chord to bed length and station distances were recorded on was dated 6/17/93. The elevation coordinates were lined up with the system surveyed for this report by the low chord points.

\begin{tabular}{|l|l|l|l|l|l|l|l|l|l|l|l|}
\hline Station & $\mathbf{0}$ & $\mathbf{1 7}$ & $\mathbf{2 6}$ & $\mathbf{3 7}$ & - & - & - & - & - & - & - \\
\hline Feature & LAB & - & - & RAB & - & - & - & - & - & - & - \\
\hline $\begin{array}{l}\text { Low chord } \\
\text { elevation }\end{array}$ & $\mathbf{4 9 7 . 3 5}$ & $\mathbf{4 9 7 . 2 8}$ & $\mathbf{4 9 7 . 2 5}$ & $\mathbf{4 9 7 . 2 1}$ & - & - & - & - & - & - & - \\
\hline $\begin{array}{l}\text { Bed } \\
\text { elevation }\end{array}$ & $\mathbf{4 9 0 . 4 5}$ & $\mathbf{4 9 0 . 6 8}$ & $\mathbf{4 9 0 . 7 5}$ & $\mathbf{4 9 1 . 9 1}$ & - & - & - & - & - & - & - \\
\hline $\begin{array}{l}\text { Low chord } \\
\text { to bed }\end{array}$ & $\mathbf{6 . 9}$ & $\mathbf{6 . 6}$ & $\mathbf{6 . 5}$ & $\mathbf{5 . 3}$ & - & - & - & - & - & - & - \\
\hline \begin{tabular}{l} 
Station \\
\hline $\begin{array}{l}\text { Feature } \\
\text { for }\end{array}$
\end{tabular}$-$ & - & - & - & - & - & - & - & - & - & - \\
\hline $\begin{array}{l}\text { Low chord } \\
\text { elevation }\end{array}$ & - & - & - & - & - & - & - & - & - & - \\
\hline $\begin{array}{l}\text { Bed } \\
\text { elevation }\end{array}$ & - & - & - & - & - & - & - & - & - & - \\
\hline $\begin{array}{l}\text { Low chord } \\
\text { to bed }\end{array}$ & - & - & - & - & - & - & - & - & - & - \\
\hline
\end{tabular}

Source (FEMA, VTAOT, Other)?

Comments: -

\begin{tabular}{|l|l|l|l|l|l|l|l|l|l|l|l|l|}
\hline Station & - & - & - & - & - & - & - & - & - & - \\
\hline Feature & - & - & - & - & - & - & - & - & - & - \\
\hline $\begin{array}{l}\text { Low chord } \\
\text { elevation }\end{array}$ & - & - & - & - & - & - & - & - & - & - & - \\
\hline $\begin{array}{l}\text { Bed } \\
\text { elevation }\end{array}$ & - & - & - & - & - & - & - & - & - & - & - \\
\hline $\begin{array}{l}\text { Low chord } \\
\text { to bed }\end{array}$ & - & - & - & - & - & - & - & - & - & - & - \\
\hline \begin{tabular}{l} 
Station \\
\hline \begin{tabular}{l} 
Feature \\
\hline
\end{tabular}
\end{tabular}$-$ & - & - & - & - & - & - & - & - & - & - \\
\hline $\begin{array}{l}\text { Low chord } \\
\text { elevation }\end{array}$ & - & - & - & - & - & - & - & - & - & - \\
\hline $\begin{array}{l}\text { Bed } \\
\text { elevation }\end{array}$ & - & - & - & - & - & - & - & - & - & - \\
\hline $\begin{array}{l}\text { Low chord } \\
\text { to bed }\end{array}$ & - & - & - & - & - & - & - & - & - & - \\
\hline
\end{tabular}


APPENDIX E:

LEVEL I DATA FORM 
U. S. Geological Survey

Bridge Field Data Collection and Processing Form

Qa/Qc Check by: $\mathbf{C G}$ Date: $\mathbf{1 / 2 4 / 9 6}$

Computerized by: $\mathbf{C G}$ Date: $2 / 2 / 96$

\section{Structure Number LUDLTH03560054}

Reviewd by:

SAW Date: $\underline{12 / 16 / 97}$

\section{A. General Location Descriptive}

1. Data collected by (First Initial, Full last name) M. Ivanoff

Date $(M M / D D / Y Y) \underline{10} / \underline{12} / \underline{1995}$

2. Highway District Number $\mathbf{0 3}$

County Windsor (027)

Mile marker $\mathbf{0}$

Waterway (I - 6) Jewel Brook

Route Number TH 356

Town Ludlow (41200)

Road Name Pond Street

3. Descriptive comments:

Hydrologic Unit Code: $\mathbf{0 1 0 8 0 1 0 6}$

This site is located 0.01 miles from the junction with town highway 2.

\section{B. Bridge Deck Observations}
4. Surface cover... LBUS 6
RBUS 2
LBDS 2
RBDS 2
Overall 2

( $2 b$ us, ds,lb,rb: 1- Urban; 2- Suburban; 3- Row crops; 4- Pasture; 5- Shrub- and brushland; 6- Forest; 7- Wetland)
5. Ambient water surface... US 2
UB 2 DS 2
(1- pool; 2- riffle)

6. Bridge structure type 1 (1- single span; 2- multiple span; 3- single arch; 4- multiple arch; 5-cylindrical culvert; 6- box culvert; or 7- other)
7. Bridge length 41.0
(feet)
Span length 37.0
(feet)
Bridge width $\underline{23.1}$ (feet)

\section{Road approach to bridge:}
8. LB $\underline{0}$ RB $\underline{0}$
( 0 even, 1- lower, 2- higher)
9. LB 1
RB 1
(1- Paved, 2- Not paved)

10. Embankment slope (run / rise in feet / foot)

US left

0.0:1

US right

0.0:1

\begin{tabular}{|c|c|c|c|c|}
\hline & \multicolumn{2}{|c|}{ Protection } & \multirow{2}{*}{ 13.Erosion } & \multirow{2}{*}{ 14.Severity } \\
\hline & 11.Type & 12.Cond. & & \\
\hline LBUS & $\mathbf{0}$ & - & $\mathbf{0}$ & $\mathbf{0}$ \\
\hline RBUS & 2 & 1 & 3 & 3 \\
\hline RBDS & 2 & 1 & 2 & 1 \\
\hline LBDS & 5 & 1 & $\mathbf{0}$ & $\mathbf{0}$ \\
\hline
\end{tabular}

Bank protection types: $\mathbf{0}$ - none; $\mathbf{1}-<12$ inches;

2- < 36 inches; 3- < 48 inches;

4- < 60 inches; 5- wall / artificial levee

Bank protection conditions: 1- good; 2- slumped;

3- eroded; 4- failed

Erosion: 0 - none; 1- channel erosion; 2 -

road wash; 3- both; 4- other

Erosion Severity: 0 - none; 1- slight; 2- moderate; 3- severe

\section{Channel approach to bridge (BF):}

15. Angle of approach: $\mathbf{0}$

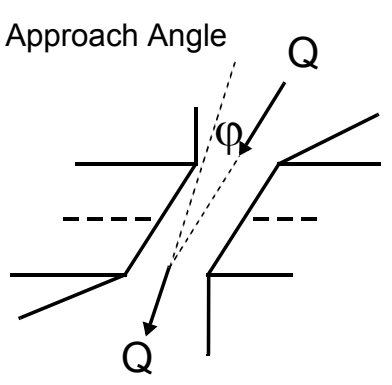

17. Channel impact zone 1 :

Where? LB (LB, RB)

Range? 10 feet $\underline{\mathbf{U S}}$

Channel impact zone 2:

Where? _ _ $(L B, R B)$

Range? - $\quad$ feet -

(US, UB, DS) to feet Impact Severity: 0- none to very slight; 1- Slight; 2- Moderate; 3- Severe

16. Bridge skew: $\mathbf{0}$ Bridge Skew Angle

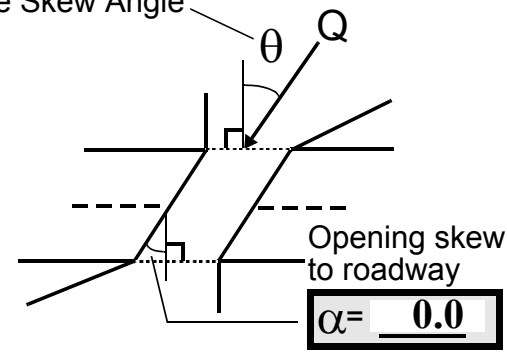

\section{Exist? $\mathbf{Y}(Y$ or $N)$}

Severity 2

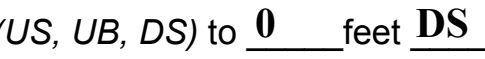

Exist? $\mathbf{N}(Y$ or $N)$

Severity - 
18. Bridge Type: 1a

1a- Vertical abutments with wingwalls

1 b- Vertical abutments without wingwalls

2- Vertical abutments and wingwalls, sloping embankment Wingwalls parallel to abut. face

3- Spill through abutments

4- Sloping embankment, vertical wingwalls and abutments

Wingwall angle less than $90^{\circ}$.

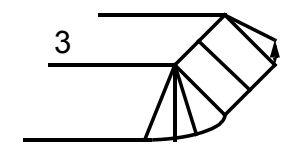

19. Bridge Deck Comments (surface cover variations, measured bridge and span lengths, bridge type variations, approach overflow width, etc.)

7. All measurements are the same as on the historical form. There is a clear span of 32.5 feet.

14. The RBUS laid up stone wall is in good condition. The concrete facing of the wingwall has spalled off. Moderate road wash is occurring at the base of upstream right curbing.

\section{Upstream Channel Assessment}

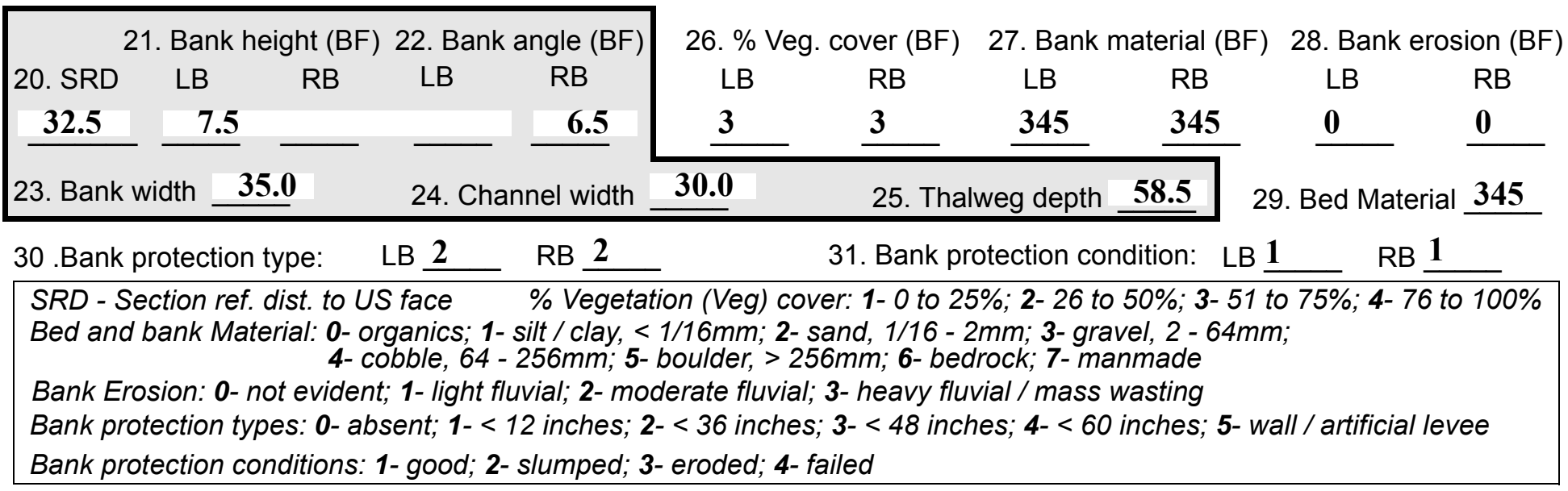

32. Comments (bank material variation, minor inflows, protection extent, etc.):

27. The bank material is composed of gravel, cobble and boulder.

29. The bed material is composed of gravel, cobble and boulder.

30. Native stone fill lines both banks beyond 200 feet upstream. A railroad bridge pier is high on the right bank (100 to 126 feet upstream). There is large boulder fill between the pier and the stream bed. 
33.Point/Side bar present? $\mathbf{N}(Y$ or $N$. if $N$ type ctrl-n pb)34. Mid-bar distance: -

35. Mid-bar width: -

36. Point bar extent: feet (US, UB) to feet (US, UB, DS) positioned $\%$ LB to $\% \mathrm{RB}$

37. Material: -

38. Point or side bar comments (Circle Point or Side; Note additional bars, material variation, status, etc.):

NO POINT BARS

39. Is a cut-bank present? $\underline{\mathbf{N}}$ (Y or if $\mathrm{N}$ type ctrl-n cb)

40. Where? (LB or $R B)$

41. Mid-bank distance: -

42. Cut bank extent: feet (US, UB) to feet (US, UB, DS)

43. Bank damage: (1- eroded and/or creep; 2- slip failure; 3- block failure)

44. Cut bank comments (eg. additional cut banks, protection condition, etc.):

NO CUT BANKS

45. Is channel scour present? $\mathbf{N}$ ( $Y$ or if $N$ type ctrl-n cs)

47. Scour dimensions: Length Width Depth : 46. Mid-scour distance: -

48. Scour comments (eg. additional scour areas, local scouring process, etc.):

NO CHANNEL SCOUR

49. Are there major confluences? $\mathbf{N}$ ( $Y$ or if $N$ type ctrl-n $m c)$

51. Confluence 1: Distance 52. Enters on (LB or $R B$ ) Confluence 2: Distance Enters on ( $L B$ or $R B$ )

54. Confluence comments (eg. confluence name):

NO MAJOR CONFLUENCES

A concrete culvert $3.5 \mathrm{ft}$ in diameter drains into the stream 151 feet upstream on the right bank.

\section{Under Bridge Channel Assessment}

55. Channel restraint (BF)? LB 2 (1- natural bank; 2- abutment; 3- artificial levee)

\begin{tabular}{|ccccc}
\multicolumn{2}{c}{ 56. Height (BF) } & \multicolumn{3}{c}{57 Angle (BF) } \\
LB & RB & LB & RB \\
37.5 & & & $\mathbf{1 . 0}$ & \\
\hline
\end{tabular}

\begin{tabular}{lc} 
61. Material (BF) \\
LB & RB \\
$\mathbf{2}$ & $\mathbf{7}$ \\
\hline
\end{tabular}

62. Erosion (BF)

LB RB

7

53. Type(1- perennial; 2- ephemeral)

Type (1-perennial; 2- ephemeral)

58. Bank width (BF) 59. Channel width (Amb) 60. Thalweg depth (Amb) $\mathbf{9 0 . 0}$ 63. Bed Material -

Bed and bank Material: 0- organics; 1- silt / clay, < 1/16mm; 2- sand, 1/16 - 2mm; 3- gravel, 2 - 64mm; 4- cobble, 64 - 256mm; 5- boulder, > 256mm; 6- bedrock; 7- manmade

Bank Erosion: 0- not evident; 1- light fluvial; 2- moderate fluvial; 3- heavy fluvial / mass wasting

64. Comments (bank material variation, minor inflows, protection extent, etc.):

345

63. The bed material is composed of gravel, cobble and boulder. 
65. Debris and Ice Is there debris accumulation?

(Yor $N)$ 66. Where? $\mathbf{N}$

(1- Upstream; 2- At bridge; 3- Both)

67. Debris Potential (1-Low; 2- Moderate; 3- High)

69. Is there evidence of ice build-up? 1 (Y or N)

68. Capture Efficiency 1

(1-Low; 2- Moderate; 3- High)

Ice Blockage Potential $\mathbf{N}$

(1-Low; 2- Moderate; 3- High)

70. Debris and Ice Comments:

1

Stream channel widens near the bridge, allowing debris flow.

\begin{tabular}{|l|c|c|c|c|c|c|c|c|}
\hline Abutments & $\begin{array}{c}\text { 71. Attack } \\
\angle \text { (BF) }\end{array}$ & $\begin{array}{c}\text { 72. Slope } \angle \\
\text { (Qmax) }\end{array}$ & $\begin{array}{c}\text { 73. Toe } \\
\text { loc. (BF) }\end{array}$ & $\begin{array}{c}\text { 74. Scour } \\
\text { Condition }\end{array}$ & $\begin{array}{c}75 . \text { Scour } \\
\text { depth }\end{array}$ & $\begin{array}{c}\text { 76. Exposure } \\
\text { depth }\end{array}$ & 77. Material & 78. Length \\
\hline LABUT & & $\mathbf{0}$ & $\mathbf{9 0}$ & $\mathbf{2}$ & $\mathbf{1}$ & $\mathbf{0 . 5}$ & $\mathbf{0}$ & $\mathbf{9 0 . 0}$ \\
\hline RABUT & $\mathbf{1}$ & $\mathbf{0}$ & $\mathbf{9 0}$ & & & $\mathbf{2}$ & $\mathbf{0}$ & $\mathbf{3 3 . 0}$ \\
\hline
\end{tabular}

Pushed: $L B$ or RB

Toe Location (Loc.): 0- even, 1- set back, 2- protrudes

Scour cond.: 0- not evident; 1- evident (comment); 2- footing exposed; 3-undermined footing; 4- piling exposed; 5- settled; 6- failed

Materials: 1- Concrete; 2- Stone masonry or drywall; 3- steel or metal; 4- wood

79. Abutment comments (eg. undermined penetration, unusual scour processes, debris, etc.):

0

0

1

74. The left abutment has a void in the concrete at the corner junction with the wingwall. The void has a maximum penetration of 0.8 feet. There is also a 1.5 feet long void with 0.3 feet penetration 5 feet under the bridge from the upstream face. The right abutment appears to have two settlement cracks starting under the last two steel beams. The structural inspection report of 6/14/93 noted that the left abutment was undermined 1 to 1.5 feet along the channel.

80. Wingwalls:

$\begin{array}{llll} & & & \\ \text { Exist? Material? } & \text { Scour } & \text { Scour } & \text { Exposure } \\ \text { Condition? } & \text { depth? } & \text { depth? }\end{array}$

USLWW:

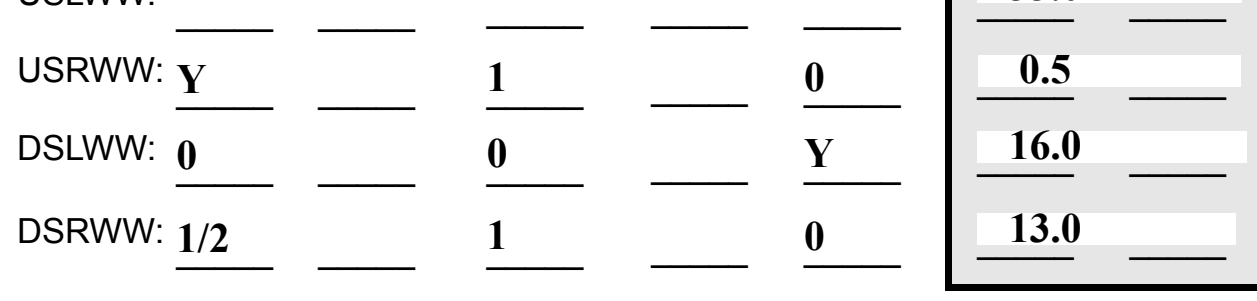

Wingwall materials: 1- Concrete; 2- Stone masonry or drywall; 3- steel or metal; 4- wood

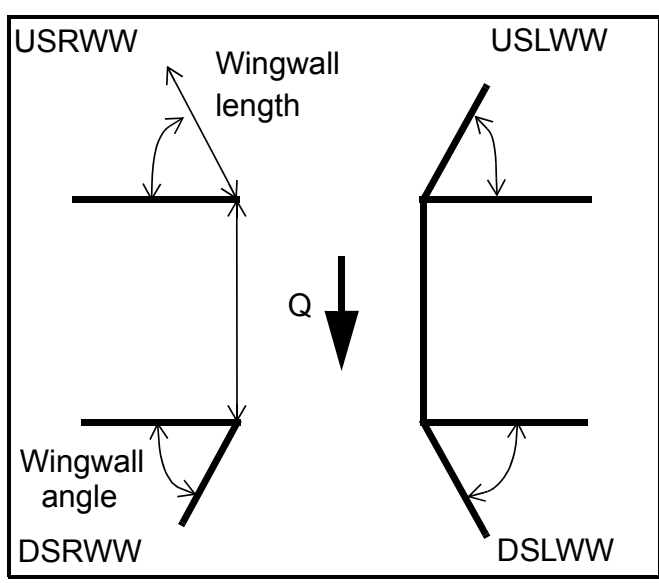

82. Bank / Bridge Protection:

\begin{tabular}{|l|l|l|l|l|l|l|c|c|}
\hline Location & USLWW & USRWW & LABUT & RABUT & LB & RB & DSLWW & DSRWW \\
\hline Type & $\mathbf{0}$ & $\mathbf{1}$ & $\mathbf{Y}$ & $\mathbf{0}$ & - & - & - & - \\
\hline Condition & $\mathbf{Y}$ & $\mathbf{0 . 5}$ & $\mathbf{1}$ & $\mathbf{0}$ & - & - & - & - \\
\hline Extent & $\mathbf{1}$ & $\mathbf{0}$ & $\mathbf{1}$ & $\mathbf{0}$ & $\mathbf{0}$ & $\mathbf{0}$ & $\mathbf{0}$ & - \\
\hline
\end{tabular}

Bank / Bridge protection types: 0- absent; 1- < 12 inches; 2- < 36 inches; 3- < 48 inches; 4- < 60 inches; 
83. Wingwall and protection comments (eg. undermined penetration, unusual scour processes, etc.):

-
-
-
-
-
0
-
-
2
1
1

\section{Piers:}

84. Are there piers? $\mathbf{8 0 .}$ ( $Y$ or if $N$ type ctrl-n pr)

\begin{tabular}{|l|r|l|l|l|l|l|l|}
\hline \multirow{2}{*}{$\begin{array}{l}85 . \\
\text { Pier no. }\end{array}$} & \multicolumn{3}{|c|}{ width (w) feet } & \multicolumn{3}{c|}{ elevation (e) feet } \\
\cline { 2 - 8 } & w1 & w2 & w3 & e@w1 & e@w2 & e@w3 \\
\hline Pier 1 & & & & $\mathbf{6 5 . 0}$ & $\mathbf{2 0 . 5}$ & $\mathbf{7 5 . 0}$ \\
\hline Pier 2 & $\mathbf{9 . 0}$ & & & $\mathbf{4 0 . 0}$ & $\mathbf{1 7 . 5}$ & $\mathbf{7 0 . 0}$ \\
\hline Pier 3 & $\mathbf{3 . 5}$ & - & - & - & - & - \\
\hline Pier 4 & - & - & - & - & - & - \\
\hline
\end{tabular}

\begin{tabular}{|l|l|l|l|l|}
\hline Level 1 Pier Descr. & \multicolumn{1}{|c|}{1} & \multicolumn{1}{|c|}{2} & \multicolumn{1}{|c|}{3} & \multicolumn{1}{|c|}{4} \\
\hline 86. Location (BF) & The & remove & am left & junc- \\
\hline 87. Type & upst & d & wing & tion \\
\hline 88. Material & ream & expo & wall & with \\
\hline 89. Shape & right & sing & has a & the \\
\hline 90. Inclined? & wing & the & void & abut \\
\hline 91. Attack $\angle$ (BF) & wall & laid & alon & ment \\
\hline 92. Pushed & con- & up & g the & to 2 \\
\hline 93. Length (feet) & - & - & - & - \\
\hline 94. \# of piles & crete & stone & wall & feet \\
\hline 95. Cross-members & fac- & wall. & from & dow \\
\hline 96. Scour Condition & ing & The & the & nstre \\
\hline 97. Scour depth & has & dow & cor- & am. \\
\hline 98. Exposure depth & been & nstre & ner & Ther \\
\hline
\end{tabular}

LFP, LTB, LB, MCL, MCM, MCR, RB, RTB, RFP

1- Solid pier, 2- column, 3- bent

1-Wood; 2- concrete; 3- metal; 4- stone

1- Round; 2- Square; 3- Pointed

Y-yes; $N-$ no

$L B$ or $R B$

0- none; 1- laterals; 2- diagonals; 3- both

0- not evident; 1- evident (comment);

2- footing exposed; 3- piling exposed;

4- undermined footing; 5- settled; 6- failed 
99. Pier comments (eg. undermined penetration, protection and protection extent, unusual scour processes, etc.):

$\mathrm{e}$ is 0.5 feet of penetration.

The downstream right wingwall has a settlement crack running down it. The wingwall has a rough end with upright timbers at the downstream end.

$\mathbf{N}$

100.

\section{E. Downstream Channel Assessment}

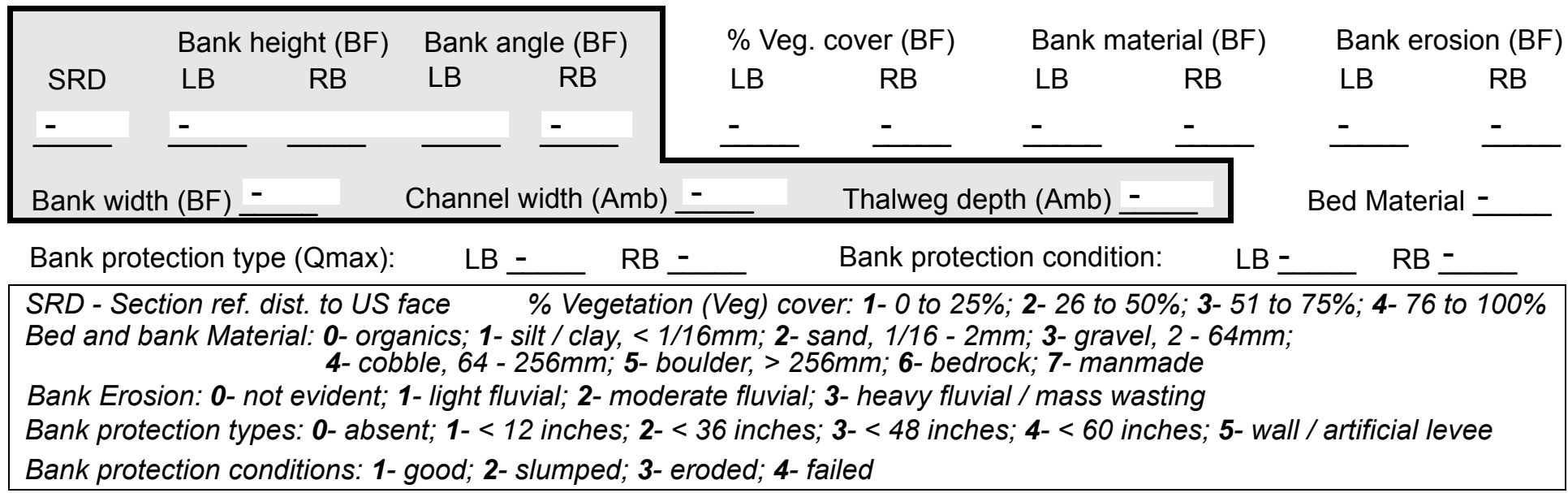

Comments (eg. bank material variation, minor inflows, protection extent, etc.):

$-$

$-$

$-$

-

-

-

-

-

-

-

$-$

-

\section{Is a drop structure present? __ (Y or N, if N type ctrl-n ds) 102. Distance: _ _ feet}
103. Drop: - feet
104. Structure material:
(1- steel sheet pile; 2- wood pile; 3- concrete; 4- other)

105. Drop structure comments (eg. downstream scour depth):

-

$-$

-

- 
106. Point/Side bar present? (Y or $N$. if $N$ type ctrl-n pb)Mid-bar distance:

Mid-bar width: -

Point bar extent: feet -

(US, UB, DS) to feet (US, UB, DS) positioned $\%$ LB to $\% \mathrm{RB}$ Material:

Point or side bar comments (Circle Point or Side; note additional bars, material variation, status, etc.):

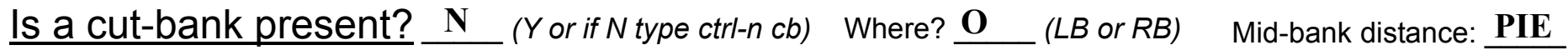
Cut bank extent: $\underline{\mathbf{R S}}$ feet ___ (US, UB, DS) to feet (US, UB, DS)

Bank damage: (1- eroded and/or creep; 2- slip failure; 3- block failure)

Cut bank comments (eg. additional cut banks, protection condition, etc.):

Is channel scour present? Scour dimensions: Length 3 Width 435 Depth: 435 Scour comments (eg. additional scour areas, local scouring process, etc.): 345

2

2

1

Are there major confluences? 1 ( 1 or if $N$ type ctrl-n $m c)$

Confluence 1: Distance strea Enters on $\underline{\mathbf{m}}$ (LB or RB)

Enters on $\mathbf{e}$ (LB or $R B)$

Mid-scour distance: $\underline{3}$

Confluence 2: Distance nativ e):

e fill lining the banks. The fill extends over 200 feet downstream.

The downstream bank material is composed of cobble, gravel and boulder.

\section{F. Geomorphic Channel Assessment}

107. Stage of reach evolution
1- Constructed

2- Stable

3- Aggraded

4- Degraded

5- Laterally unstable

6- Vertically and laterally unstable 
108. Evolution comments (Channel evolution not considering bridge effects; See HEC-20, Figure 1 for geomorphic descriptors):

e downstream bed material is composed of gravel, cobble, and boulder. 


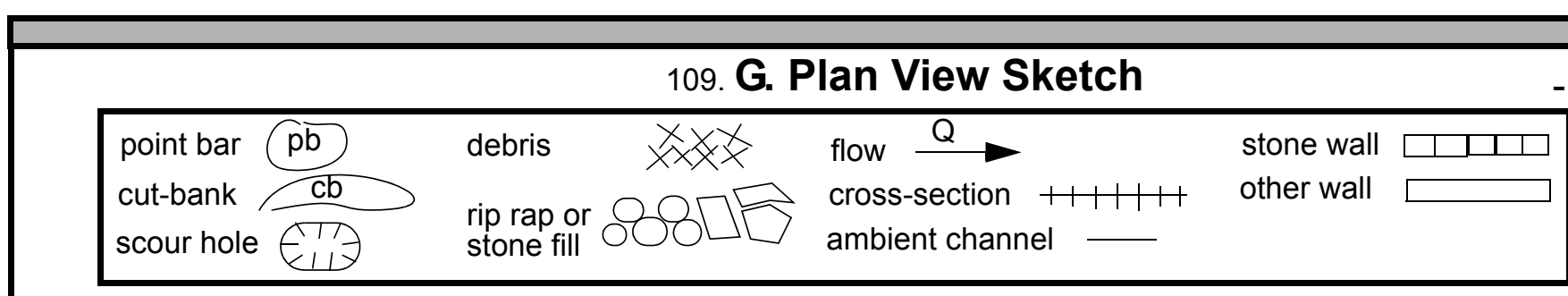


APPENDIX F:

SCOUR COMPUTATIONS 
SCOUR COMPUTATIONS

\begin{tabular}{|c|c|c|c|}
\hline $\begin{array}{ll}\text { Structure Number: LUDLTH03560054 } \\
\text { Road Number: } & \text { TH356 }\end{array}$ & & $\begin{array}{l}\text { Town : } \\
\text { County: }\end{array}$ & $\begin{array}{l}\text { LUDLOW } \\
\text { WINDSOR }\end{array}$ \\
\hline Stream: JEWELL & & & \\
\hline Initials SAW & Checked: & MAI & \\
\hline Analysis of contraction scour, live & -bed or $\mathrm{c}$ & lear wate & \\
\hline $\begin{array}{l}\text { Critical Velocity of Bed Material } \\
\text { VC=11.21*y1^0.1667*D50^0.33 with Ss } \\
\text { (Richardson and others, 1995, p. } 28\end{array}$ & $\begin{array}{l}\text { converted } \\
=2.65 \\
\text { eq. 16) }\end{array}$ & to Engli & sh units) \\
\hline Approach Section & & & \\
\hline Characteristic & $100 \mathrm{yr}$ & $500 \mathrm{yr}$ & Q incipient \\
\hline Total discharge, cfs & 1770 & 2400 & 1660 \\
\hline Main Channel Area, ft2 & 332 & 385 & 248 \\
\hline Left overbank area, ft2 & 0 & 0 & 0 \\
\hline Right overbank area, ft2 & 0 & 6 & 0 \\
\hline Top width main channel, ft & 55 & 57 & 50 \\
\hline Top width L overbank, ft & 0 & 0 & 0 \\
\hline Top width $\mathrm{R}$ overbank, ft & 0 & 13 & 0 \\
\hline D50 of channel, ft & 0.28878 & 0.28878 & 0.28878 \\
\hline D50 left overbank, ft & -- & -- & -- \\
\hline D50 right overbank, ft & -- & -- & -- \\
\hline y1, average depth, MC, ft & 6.0 & 6.8 & 5.0 \\
\hline Y1, average depth, LOB, ft & ERR & ERR & ERR \\
\hline Y1, average depth, ROB, ft & ERR & 0.5 & ERR \\
\hline Total conveyance, approach & 22313 & 28108 & 14687 \\
\hline Conveyance, main channel & 22313 & 28004 & 14687 \\
\hline Conveyance, LOB & 0 & 0 & 0 \\
\hline Conveyance, ROB & 0 & 104 & 0 \\
\hline Percent discrepancy, conveyance & 0.0000 & 0.0000 & 0.0000 \\
\hline Qm, discharge, $\mathrm{MC}$, Cfs & 1770.0 & 2391.1 & 1660.0 \\
\hline Q1, discharge, LOB, cfs & 0.0 & 0.0 & 0.0 \\
\hline Qr, discharge, ROB, cfs & 0.0 & 8.9 & 0.0 \\
\hline $\mathrm{Vm}$, mean velocity $\mathrm{MC}$, ft/s & 5.3 & 6.2 & 6.7 \\
\hline $\mathrm{VI}$, mean velocity, LOB, ft/s & ERR & ERR & ERR \\
\hline Vr, mean velocity, ROB, ft/s & ERR & 1.5 & ERR \\
\hline Vc-m, crit. velocity, $\mathrm{MC}$, ft/s & 10.0 & 10.2 & 9.7 \\
\hline VC-l, crit. velocity, LOB, ft/s & ERR & ERR & ERR \\
\hline Vc-r, crit. velocity, ROB, ft/s & ERR & ERR & ERR \\
\hline Results & & & \\
\hline Live-bed(1) or Clear-Water(0) Contr & action $\mathrm{Scc}$ & bur? & \\
\hline Main Channel & 0 & 0 & 0 \\
\hline Left Overbank & $\mathrm{N} / \mathrm{A}$ & $\mathrm{N} / \mathrm{A}$ & $\mathrm{N} / \mathrm{A}$ \\
\hline Right Overbank & $\mathrm{N} / \mathrm{A}$ & $\mathrm{N} / \mathrm{A}$ & $\mathrm{N} / \mathrm{A}$ \\
\hline
\end{tabular}


Clear water Contraction Scour in MAIN CHANNEL

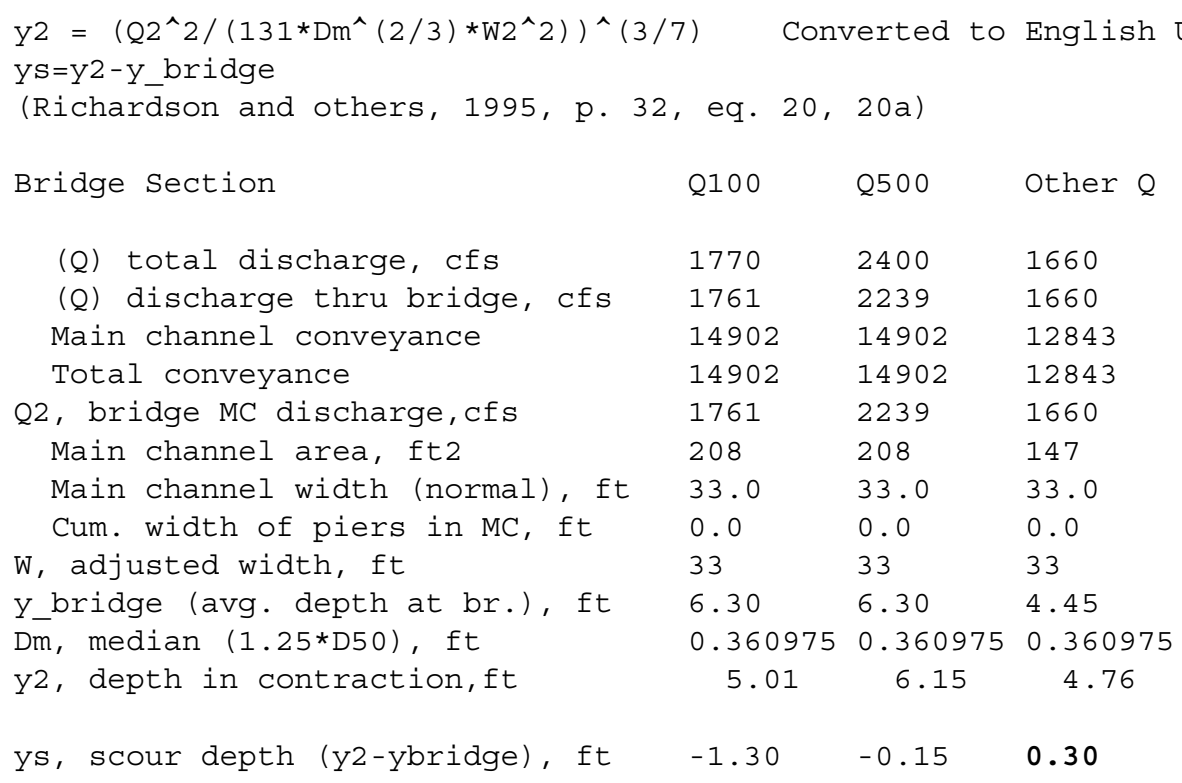

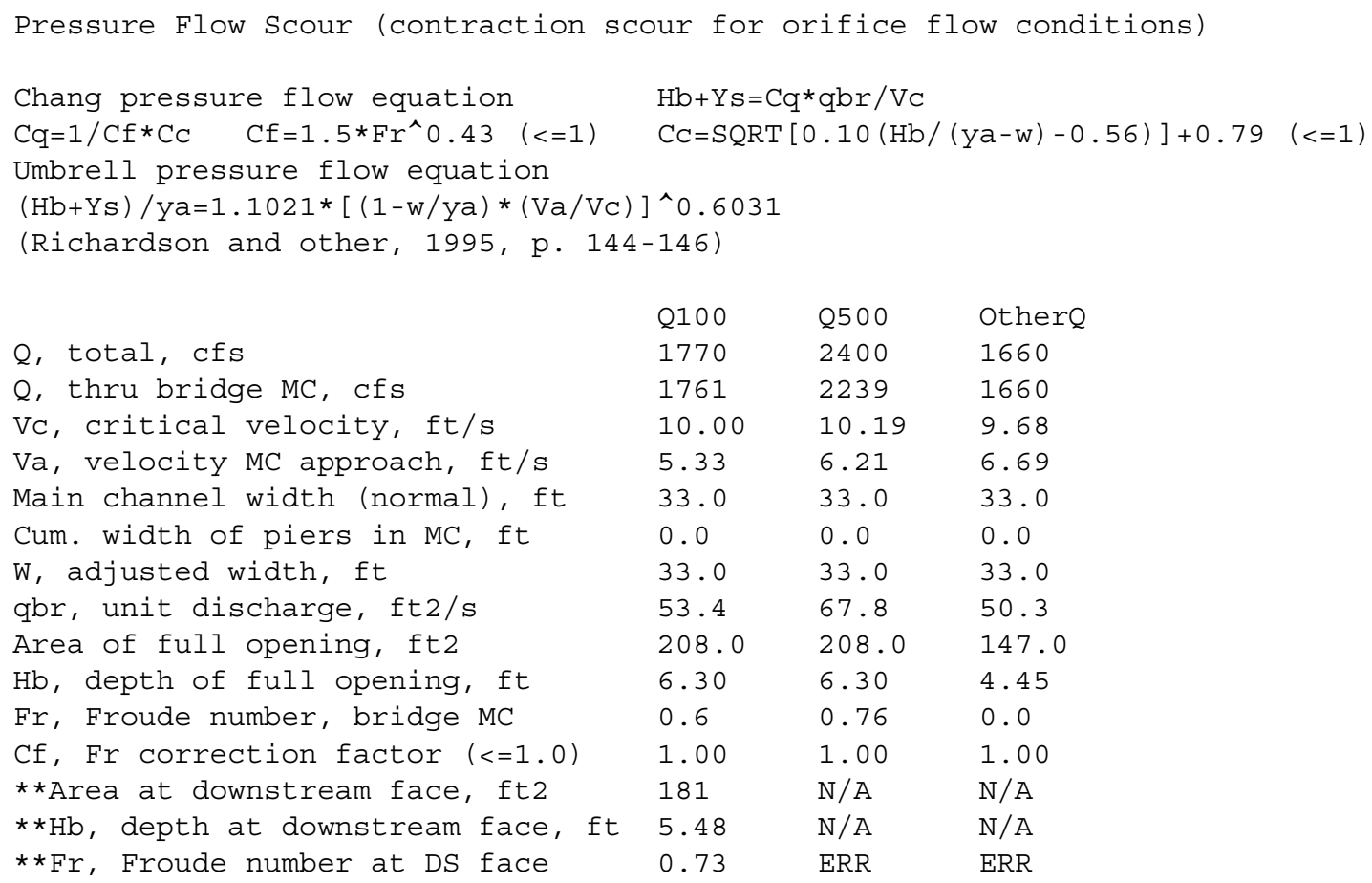




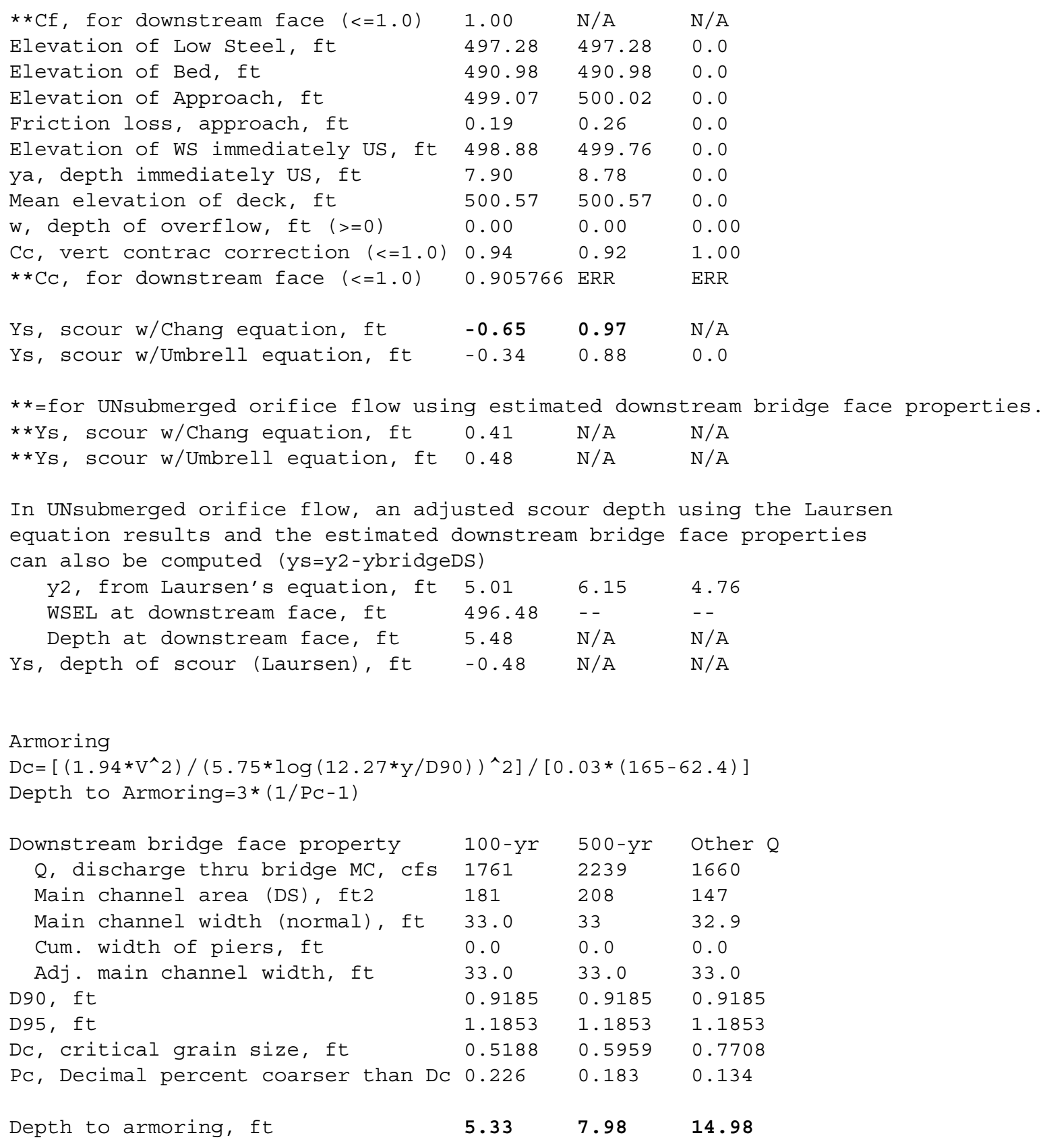

Abutment Scour

Froehlich's Abutment Scour

$\mathrm{Ys} / \mathrm{Y} 1=2.27 * \mathrm{~K} 1 * \mathrm{~K} 2 *\left(\mathrm{a}^{\prime} / \mathrm{Y} 1\right)^{\wedge} 0.43 * \mathrm{Fr} 1 \wedge 0.61+1$

(Richardson and others, 1995, p. 48, eq. 28)

Characteristic

(Qt), total discharge, cfs

$a^{\prime}$, abut.length blocking flow, ft

Ae, area of blocked flow ft 2

Qe, discharge blocked abut., cfs
Left Abutment 100 yr Q 500 yr Q Other Q 100 yr Q 500 yr Q Other Q

Right Abutment

$\begin{array}{llllll}1770 & 2400 & 1660 & 1770 & 2400 & 1660 \\ 15.1 & 16.4 & 13.0 & 7 & 20.5 & 4.5 \\ 68.29 & 83.62 & 46.7 & 21.52 & 33.57 & 11.95 \\ 286.57 & 403.64 & 242.1 & 65.21 & 112.84 & 45.55\end{array}$




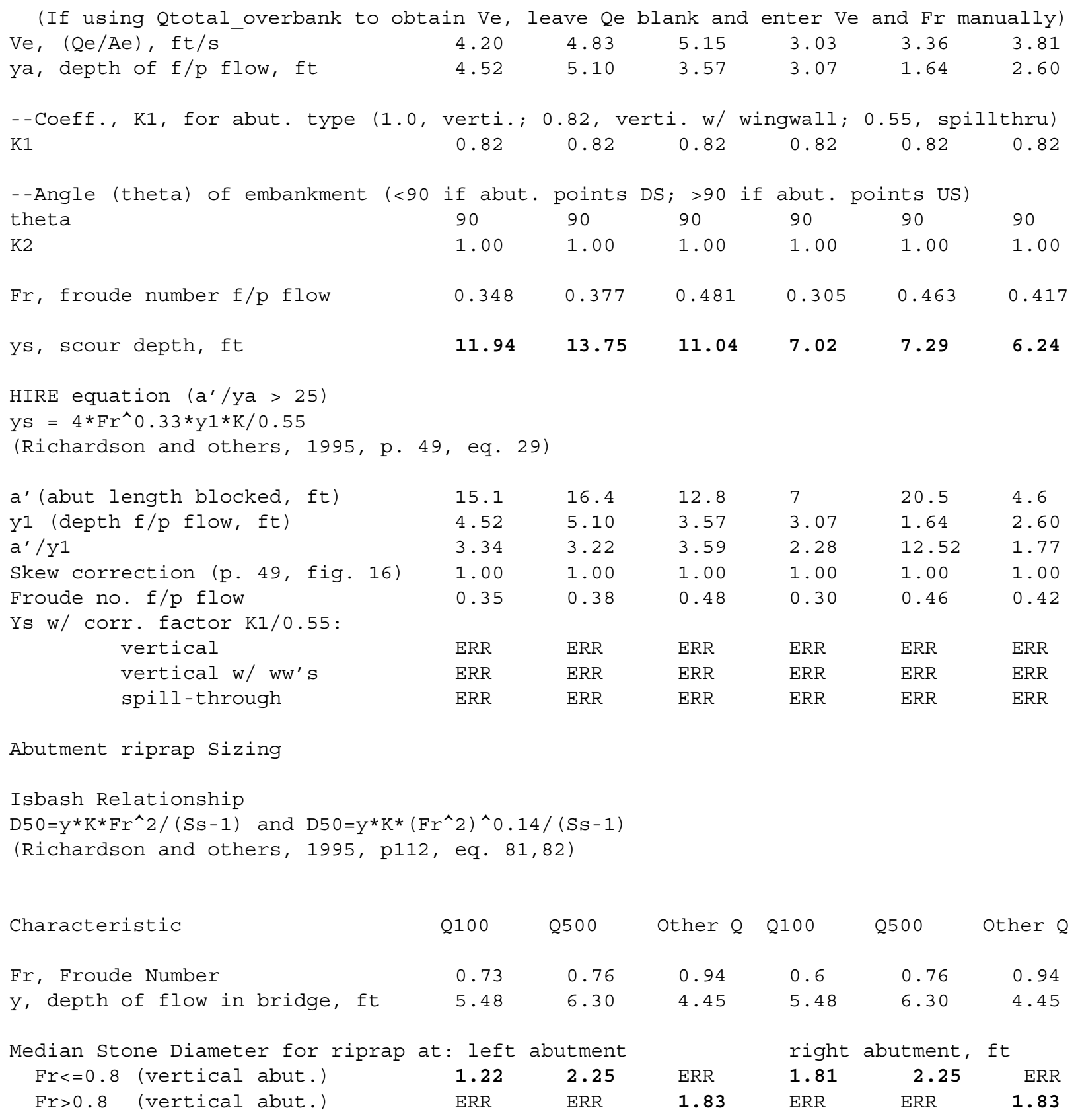


